\title{
An inverse model of the large scale circulation in the South Indian Ocean
}

\author{
E. Sultan ${ }^{a^{*}}$, H. Mercier ${ }^{b}$, R.T. Pollard ${ }^{c}$ \\ ${ }^{a}$ Muséum National d'Histoire Naturelle, Laboratoire d'Océanographie et du Climat:Expérimentation et Approche \\ Numérique, Institut Pierre Simon Laplace, Université Pierre et Marie Curie, Case 100, 4 place Jussieu, 75252 \\ Paris Cedex 05, FRANCE. \\ ${ }^{\mathrm{b}}$ laboratoire de Physique des Océans, LPO, B.P.70,29280 PLOUZANE, France \\ ${ }^{c}$ National Oceanography Centre, Southampton, European Way,Southampton SO14 3ZH, U. K. \\ *: Corresponding author : Emmanuelle.Sultan@locean-ipsl.upmc.fr
}

\begin{abstract}
An overview of the large-scale circulation of the South Indian Ocean (SIO) $\left(10^{\circ} \mathrm{S}-\right.$ $\left.70^{\circ} \mathrm{S} / 20^{\circ} \mathrm{E}-120^{\circ} \mathrm{E}\right)$ is proposed based on historical hydrographic data (1903-1996) synthesized with a finite-difference inverse model. The in situ density, potential temperature and salinity fields of selected hydrographic stations are projected on the basis of EOFs. Then the EOF coefficients (the projected values) are interpolated on the model grid ( $1^{\circ}$ in latitude, $2^{\circ}$ in longitude) using an objective analysis whose spatial correlation functions are fitted to the data set. The resulting fields are the input of the inverse model. This procedure filters out the small-scale features. Twelve modes are needed to keep the vertical structures of the fields but the first three modes are sufficient to reproduce the large-scale horizontal features of the SIO: the Subtropical Gyre, the Weddell Gyre, the different branches of the Antarctic Circumpolar Current.
\end{abstract}

The dynamics is steady state. The estimated circulation is in geostrophic balance and satisfies mass, heat and potential vorticity conservation. The wind and air-sea heat forcing are annual means from ERS1 and ECMWF, respectively.

The main features of the various current systems of the SIO are quantified and reveal topographic control of the deep and bottom circulation. The cyclonic Weddell Gyre, mainly barotropic, transports 45 Sv $\left(1 \mathrm{~Sv}=10^{6} \mathrm{~m}^{3} / \mathrm{s}\right)$, and has an eastern extension limited by the southern part of the Antarctic Circumpolar Current.

The bottom circulation north of $50^{\circ} \mathrm{S}$ is complex. The Deep Western Boundary Currents are identified as well as cyclonic recirculations. South east of the Kerguelen Plateau, the bottom circulation is in good agreement with previous water mass analysis. The comparison between some recent regional analysis and the inverse estimation is limited by the model resolution and lack of deep data.

The meridional overturning circulation (MOC) is estimated from the finite difference inverse model. Between $26^{\circ} \mathrm{S}$ and $32^{\circ} \mathrm{S}$ the reversal of the current deepens and reaches $1400 \mathrm{~m}$ at $32^{\circ} \mathrm{S}$. The major part of the deep meridional transport at $32^{\circ} \mathrm{S}$ is located between the African coast and the Madagascar Ridge, carried by the Agulhas Undercurrent. The mean value for this meridional thermohaline recirculation is $8.8 \pm 4.4 \mathrm{~Sv}$ between $26^{\circ} \mathrm{S}$ and $32^{\circ} \mathrm{S}$. The Agulhas Undercurrent (11 Sv) is associated with a weak Agulhas Current ( $55 \mathrm{~Sv}$ ). The MOC is thus trapped in the western margin of the Southwest Indian Ridge. The corresponding vertical velocity along $32^{\circ} \mathrm{S}$ between $30^{\circ} \mathrm{E}$ and $42^{\circ} \mathrm{E}$ is $7.2 \times 10^{-5} \pm 8.9 \times 10^{-5} \mathrm{~cm} \mathrm{~s}^{-1}$. The net meridional heat flux represents $-0.53 \mathrm{PW}$ at $18^{\circ} \mathrm{S}$ and -0.33 $\mathrm{PW}$ at $32^{\circ} \mathrm{S}$ (negative values for southward transports). The intensity of the meridional heat flux is linked to the intensity of the Agulhas Current and to the vertical mixing.

Keywords: Southern Indian Ocean; Inverse model; Antarctic Circumpolar Current; Weddell Gyre; Meridional overturning circulation; Mean circulation 


\section{Contents}

Introduction and background

I.Data

I.1. Topography

I.2. Air-sea forcing data

I.3. Hydrographic data

I.3.1. Type

I.3.2. Data quality control and sorting procedure

II.Hydrographic data processing

II.1. The optimal interpolation method

II.2. Choice of the mean value

II.3. Results

III. The Finite difference inverse model

III.1. Formalism

III.2. A priori estimation

III.2.1 Initial covariance matrices

III.2.2. Initial choice of the Level of No Motion

III.3. Constraint contribution

III.4. General attributes of the inversion

III.4.1. Top-to-bottom integrated transport

III.4.2. Error map

III.4.3. Sensitivity to the a priori level of no motion

IV. Analysis of the estimated circulation

IV.1.Integrated transports

IV.1.1Analysis Tool - Stream function definition

IV.1.2.Diagnostics

IV.1.2.1. The Subtropical Gyre

IV.1.2.2. The Antarctic Circumpolar Current

IV.1.2.3. The Weddell gyre

IV.1.3. Discussion

IV.1.3.1. Is the non-synopticity of the data set a problem?

IV.1.3.2.Topographic control

IV.1.3.3. Are the fronts and the transports linked north of Kerguelen?

IV.2. Abyssal circulation

IV.2.1. Mozambique and Crozet Basins

IV.2.2. Bottom waters sources and pathways discussion

IV.3.The meridional overturning circulation

IV.3.1. Issue

IV.3.2. Indonesian Throughflow estimation

IV.3.3. Quantification of the MOC

IV.3.3.1. Mean value and location

IV.3.3.2. Induced vertical velocity

IV.3.4. Meridional transport across $32^{\circ} \mathrm{S}$

IV.3.5. The MOC and the Agulhas System

IV.3.5.1. The MOC and the Agulhas Undercurrent

IV.3.5.2. The MOC and heat fluxes

Conclusion and prospects 


\section{Introduction and background}

The purpose of this paper is to provide an overview of the large-scale circulation of the southern part of the Indian Ocean including the Indian sector of the Southern Ocean (called in the following the South Indian Ocean, SIO). The large-scale ocean circulation in the SIO is forced by the wind stress and buoyancy forcing at the surface and strongly depends on the bottom topography. The circulation can be deduced from measurements of temperature and salinity by the dynamic method based on geostrophic and hydrostatic balances (Pond \& Pickard, 1983). The geostrophic velocity is known relative to a reference level of no motion (LNM) which is classically deduced from water mass analysis. Previous studies have provided hydrographic data syntheses of the Indian Ocean (Wyrtki, 1971; Park \& Gambéroni, 1995; Reid, 2003), using geostrophic calculations. Other studies deal with regional analyses of the SIO such as Read and Pollard (1999) and Pollard and Read (2001) for the Southwest Indian Ocean, Park and Gambéroni (1997) for the Crozet Basin, Haine, Liddicoat and Dickson (1998) for the Kerguelen Gap (deep passage between Crozet and Kerguelen) and Beal and Bryden (1999) for reanalysis of the $32^{\circ} \mathrm{S}$ section. Park and Gambéroni (1995) compared the dynamic height fields computed from Topex/Poseidon altimetric data with outputs of the Fine Resolution Antarctic Model FRAM (Webb, Killworth, Coward \& Thompson, 1991) and with historical hydrological data (Levitus, 1982 with additional CTD data collected up to 1995 by the French community). Their main result was that the dynamic height fields computed both from altimetry and model revealed features not resolved by the hydrographic data. As a result analysis of the large-scale circulation in the SIO needs tools which combine observations and dynamics. Such tools are called inverse models (Wunsch, 1996; Mercier , Ollitrault \& Le Traon 1993) which have been intensively used and improved during WOCE. Those techniques estimate the velocity at the reference level compatible with selected constraints. Most of them have been applied to the relatively rich North Atlantic data set (Marotzke \& Willebrand 1996, for a review). In the SIO, inverse models based on coast to coast sections (here called box inverse models) have been successfully applied (Toole \& Warren 1993; MacDonald 1998, Ganachaud, Wunsch, Marotzke \& Toole, 2000; Sloyan \& Rintoul 2001). Those models have provided optimal velocity fields allowing transport estimates to be made across the sections. Such models determined global budgets. They are particularly useful for the estimation of the MOC (section V.3). In this study the nonlinear inverse model developed by Mercier et al. (1993) is used. This model differs from box inverse models because it controls both the initial density field and the velocity at the reference level and seeks an estimate of the circulation on a finite difference grid.

Because of the Eurasian continent, the atmospheric heat gain has to be balanced by interoceanic exchanges (Ffield, 1997). The Indian Ocean has open boundaries in subtropical and tropical zones, allowing exchanges with the Pacific Ocean through the Indonesian archipelago and with the Atlantic via the Agulhas Retroflection Current south of Africa. The other interoceanic exchange takes place in the Southern Ocean via the Antarctic Circumpolar Current (ACC) system.

The finite difference model is the tool choosen here to address some of the open questions in the SIO. We focus on the quantification and pattern of transport in the Subtropical Gyre, in the ACC, in the Weddell Gyre; and on the quantification and location of the MOC. The hydrological data come from the NODC data (Levitus Burgett \& Boyer, 1994) and WOCE CTD data that were available up to 1996.

The finite difference inverse model (Mercier et al., 1993) requires a high quality initial circulation, the data and the data processing are a key task presented in the first and second 
sections. The third section of this paper deals with the inverse technique and its validation to estimate the general circulation of the SIO. The fourth and final section focuses on analysis of the model results for the large-scale circulation of the SIO. We discuss the integrated transports for the Subtropical Gyre, the ACC and the Weddell Gyre. Then we present a detailed comparison of the MOC estimated from the inverse model with other estimates from both observations and models. We end with conclusions and prospects.

\section{Data}

\section{I.1. Topography}

We use the 5' resolution ETOPO5 bathymetry (Fig. 1). The SIO has a number of ridges, which create an east west asymmetry of the topography in the tropics and subtropics. In the west, there are small basins: the Agulhas, Mozambique, Madagascar and Crozet Basins. In the east, there are wider basins: the Central Indian, North Australian and the South Australian Basins. The same asymmetry also exists in the Southern Ocean due to the Kerguelen Plateau, which is a northwest to southeast barrier for the bottom circulation separating the Weddell-Enderby Basin from the Australian-Antarctic Basin. Several faults, which are pathways for the bottom circulation, cut the ridges.

\section{I.2. Air-sea forcing data}

The wind data come from ERS1 and have been averaged over 1991-95 (Park \& Guernier 2001).

The air-sea heat flux is the ECMWF (European Center for Medium -Range Weather Forecasts) reanalysis averaged for the period $1979-1993$. The heat flux resolution is $1.125^{\circ} \mathrm{X}$ $1.125^{\circ}$.

\section{I.3. Hydrographic data}

\section{I.3.1. Type}

Most of the 30000 hydrographic profiles available in the NODC data set (World Ocean Atlas Levitus, 1994, CD-ROM WOA94-04) for the SIO are pre-WOCE data. They include the sections at $18^{\circ} \mathrm{S}$ (Warren 1981a), at $32^{\circ} \mathrm{S}$ (Toole \& Warren, 1993) and the SUZIL cruise (Park, Gamberoni \& Charriaud, 1993). The $32^{\circ} \mathrm{S}$ section has been intensively studied through box inverse models (Macdonald \& Wunsch, 1996; Macdonald 1998; Ganachaud et al. 2000; Sloyan \& Rintoul 2001) to diagnose the meridional transport in the SIO. It has been also reanalyzed with new direct current measurements (Bryden \& Beal, 2001; Donahue \& Toole, 2003). An expanded discussion on this topic is given in section V.3. The WOCE hydrographic sections are the JADE1-2 (Java Australia Dynamic Experiment Program, August 1989 and February 1992, Fieux, LODYC, Paris, France) and the I6 WOCE/CIVA1-2 (Circulation et Ventilation Australes, March 1993, and March 1996, Poisson, LBCM, Paris, France), located along $30^{\circ} \mathrm{E}$ between Africa and Antarctica.

Most of the data were collected after the International Geophysical Year of 1957. The CTD data were mainly collected in the late 1980's and 1990's corresponding to the beginning of the WOCE years.

\section{I.3.2. Data quality control and sorting procedure}

We used the NODC quality control flags to select high quality data. We also only considered casts deeper than 200m to avoid coastal bias. The 16022 selected casts were collected between 1903 and 1996: 89.25\% of the casts are bottle data, 10.75\% are CTD data. Since the spatial distribution is not homogeneous, and to avoid local over-sampling, we only 
kept the deepest cast within a radius of $20 \mathrm{~km}$ (Sultan 2001). This also removes redundant data. We then considered all casts in a $10^{\circ} \times 10^{\circ}$ box and discarded salinity and temperature values larger than 3 times the box standard deviation. At this point, $43 \%$ of the 7607 remaining profiles sample the layers above $1100 \mathrm{~m}$. To give the same weight to the surface and the deep layers during data processing, we decided to select only top to bottom profiles by adding two additional selection criteria: The top measurement has to be within $50 \mathrm{~m}$ of the surface; The distance between the deepest measurement and the bottom has to be less than $25 \%$ of the total water depth. There are 1986 hydrographic stations in the final data set (Fig. 1). The data are selected (or interpolated) to 30 standard levels from the surface to $5500 \mathrm{~m}$.

\section{Hydrographic Data processing}

\section{II.1. The optimal interpolation method}

Following Mercier et al. (1993), the in-situ density, potential temperature and salinity fields are projected on the basis of EOFs calculated as the eigenvectors of the covariance matrix of the vertical profiles. Such a method has been intensively used in the 90's: for the North Atlantic Ocean (Fukumori \& Wunch, 1991; Mercier et al., 1993; Paillet \& Mercier, 1997), for the Southern Atlantic Ocean (Maamaatuaiahutapu, 1994; Larqué, 1996), and for the Indian Ocean (Jamous, 1991). This procedure allows us to conserve most of the vertical variance while filtering out small-scale features by truncating the highest eigenvectors. The mean profiles for calculation of the covariances are computed as area averages in latitude bands with a meridional extent of $15^{\circ}$. Four zones are thus defined, from south to north: the Antarctic Zone (AAZ, 364 hydrographic stations), the Subantarctic Zone (SAZ, 545 stations), the Subtropical Zone (STZ, 542 stations) and the Tropical Zone (TZ, 535 stations). The majority of the hydrographic data are located in the SAZ, the STZ and the STZ. In the SAZ and the STZ, there is a lack of data between $75^{\circ} \mathrm{E}$ and $105^{\circ} \mathrm{E}$. Regarding the vertical distribution of the data, there is a lack of deep data (below 1750m). At the deepest level $(5500 \mathrm{~m})$, there are only 6 data values for the whole AAZ, 7 in the SAZ, 7 in the STZ and 29 in the TZ. The EOF decomposition allows us to project the initial 3D field on vertical modes. The projection coefficients are called the horizontal EOF coefficients.

The horizontal EOF coefficients are interpolated onto the model grid using objective analysis (Bretherton, Davis \& Fandry, 1976). The key point of this method is the definition of the spatial correlation function of the signal to be analyzed and the amplitude of the noise in the data. No systematic procedure exists to determine this function. We follow Fukumori and Wunsch (1991) who used a sum of Gaussian functions. We use four length scales: $2000 \mathrm{~km}$, $1000 \mathrm{~km}, 500 \mathrm{~km}, 250 \mathrm{~km}$, which define the four Gaussian components of the correlation function. The noise or the unresolved mesoscale signal is defined initially by the data variance in a $200-\mathrm{km}$ diameter circle. The estimation of the variance associated with each length scale is the result of a non-linear least squares fit to the data-derived correlation function (see Mercier et al., 1993). For the gravest modes, the maximum variance is found at the largest scale $(2000 \mathrm{~km})$. For modes of higher order, the smaller scale is dominant. The highest modes are associated with the smallest scales in the horizontal. Omitting the highest mode numbers filters out the smaller scale signals. We present now the main results of this decomposition. 


\section{II.2. Results}

The number of modes necessary to reconstruct the fields depends on the tracer types, the zone and the features of interest (water masses, gyres and fronts). The minimum number of EOFs necessary to preserve more than $90 \%$ of the initial vertical variance depends on the latitude band. In the AAZ, the potential temperature variance is maximum subsurface at the level of the Winter Water (WW). In the SAZ, 5 modes are enough both for salinity and potential temperature. In the STZ and the TZ, 10 modes are needed, those two last zones being much more variable in the upper $1000 \mathrm{~m}$ than the Southern Zones.

The vertical structures of the EOFs vary depending on the type of tracer (temperature or salinity) similarly to what was observed in the Southern Atlantic (Larqué, 1996). We compared the reconstructed fields along two well-known sections at $32^{\circ} \mathrm{S}$ and at $30^{\circ} \mathrm{E}$ to the original data. For both sections five modes allow us to rebuild the first 1500 -m but 12 modes are needed to rebuild the top-to-bottom stratification. In the following, 12 modes are kept for all tracers.

The large-scale features of the SIO circulation (Subtropical Gyre, Weddell gyre, branches of the ACC) are reproduced by the horizontal EOF coefficients associated with the first 3 density modes (Fig.2).

Classically the fronts are defined using subsurface hydrological characteristics (Belkin \& Gordon, 1996). We present thus in Fig. 3 the tracer maps at $200 \mathrm{~m}$ reconstructed using 12 EOFs and the associated error maps. The east-west asymmetric pattern is conserved in both the subtropical area and the southern zone. The reconstructed in-situ density field (Fig 3), shows that the ACC comprises several branches. The Agulhas Current and its retroflection are well marked. The errors estimated by the objective analysis are maximum in regions where data are few especially between the Broken Plateau and the Kerguelen Plateau. This is also the case south of Australia. At $30^{\circ} \mathrm{E}$, the error bars are smaller due to the incorporation of the WOCE/I6 section.

To validate the reconstructed fields, we finally examine the $30^{\circ} \mathrm{E}$ sections (Fig. 4) of the salinity field. The subduction of AAIW around $45^{\circ} \mathrm{S}$ on the $30^{\circ} \mathrm{E}$ section and the outcropping of the CDW at the Antarctic shelf (limited by the 34.75 salinity isoline) are conserved.

The EOF decomposition and the Objective Analyses of the EOF coefficients create a new set of data on a regular grid $\left(1^{\circ} \times 2^{\circ}\right)$ and provide the error-maps associated with the interpolation process. At the same time, truncation of the highest modes has filtered out the small-scale features. This new climatology constitutes the input to the finite difference inverse model. Its horizontal resolution is a compromise between the actual resolution allowed by the data and the computational burden. 


\section{The finite difference inverse model}

\section{III.1. Formalism}

For a detailed description of the finite difference inverse model the reader is referred to previous papers cited in the introduction. The method is based on the geostrophic dynamics suitable for large-scale motions. The relative horizontal velocity field is calculated using the thermal wind equation. The vertical velocity is deduced from the continuity equation. To estimate the absolute velocity, the horizontal velocity at a reference level (RL) has to be determined. This velocity is one of the unknowns of the problem. The velocity at the RL is adjusted depending on the choice of the error covariance matrices and the choice of the number of constraints to be used in the inversion procedure and will be estimated by the model. Classically the RL is chosen where the velocity is expected to be very small or where its sign is changing: the level of no motion (LNM). Water mass analysis often gives a clue to the choice of the LNM. In our case, we set the initial value of the velocity at the RL to zero. The in-situ density field is also adjusted from its initial value, which depends on the objective analysis. The estimated values after inversion have to respect the following constraints:

- The estimated in-situ density, $\rho$, is "as close as possible" to the initial value, $\rho_{0}$.

- The estimated velocity at the RL, vr, is "as close as possible" to the initial value, vro.

- The residuals, $r$, for mass, heat, salt and potential vorticity conservation constraints have to be "as close as possible" to zero.

The expressions "as close as possible" are used in a least-squares sense. In other words, the inversion is the minimization of the following cost function $S_{c}$ :

$$
\mathrm{S}_{\mathrm{c}}=\left(\rho-\rho_{0}\right) \mathrm{C}_{\rho^{-1}}\left(\rho-\rho_{0}\right)+\left(\mathbf{V r}-\mathbf{V}_{\mathbf{r} 0}\right) \mathrm{C}_{\mathrm{vr}^{-1}}\left(\mathbf{V}_{\mathbf{r}}-\mathbf{V}_{\mathbf{r} 0}\right)+\mathrm{r} \mathrm{Cr}^{-1} \mathbf{r}
$$

where $\mathrm{C}_{\rho}^{-1}$, $\mathrm{Cvr}^{-1}$ and $\mathrm{Cr}^{-1}$ represent the inverse of the error covariance matrices associated with the in-situ density field, the velocity at the RL and the dynamical model respectively. Those matrices play the role of weight matrices for the cost function $\mathrm{S}_{c}$, being a non-linear function of $\rho$ and $\mathbf{v r}$. An iterative quasi-Newtonian method (minimization of $S_{c}$ ) computes the optimal solution for $\rho$ and $\mathbf{v r}$ (Tarantola \& Valette, 1982).

The method depends on the initial in-situ density field, on the first guess of the velocity at the RL imposed to zero before the inversion and on the associated error bars. As a result such a method requires high quality knowledge of the initial circulation and its error covariance.

\section{III.2. Criteria for the best initial circulation \\ III.2.2. Initial covariance matrices}

Except for the error covariance matrix of the initial density field, which is provided by the objective analysis, no systematic method exists to evaluate the other error covariance matrices. They are diagonal matrices as errors are supposed to be uncorrelated. The standard deviation at the RL is fixed at 0.02 m.s $^{-1}$. For the error covariance matrix associated with the dynamical constraints, the values of the standard deviations are chosen along the lines defined by Mercier et al. (1993) and Paillet and Mercier (1997), which reflect the uncertainty in the air-sea fluxes, and the contribution of subgrid processes. For the mass integrated transport, residuals must have the same order of magnitude as the Evaporation - Precipitation fluxes (E $\mathrm{P})$ at the air-sea interface. The E-P flux is computed from the ECMWF data. The associated standard deviation is $2.4 \times 10^{5} \mathrm{~kg}^{-s^{-1}}$ and applied on each surface of the model box. The heatintegrated transport is deduced from the ECMWF net flux. The associated standard deviation is $4 \mathrm{x} 1012 \mathrm{~W}$ for each model box. The standard deviation associated with the residuals for the planetary vorticity balance at the reference level is of the same order as the standard deviation of the vertical velocity. In the World Ocean, the mean vertical velocity is estimated at $10^{-5}$ m.s-1, but the standard deviation is not known and is here fixed to $2.510^{-5} \mathrm{~m}^{-1} \mathrm{~s}^{-1}$. This constraint is applied to boxes with no corner on the coast. Indeed the planetary vorticity 
balance is not respected where non-linear processes such as coastal upwelling occur.

\section{III.2.1. Initial choice of the Reference Level}

The initial circulation is computed using the thermal-wind equations assuming a reference level where the velocity is set to zero as a first guess. After inversion, the velocity at the reference level RL is adjusted depending on the choice of the error covariance matrices and the choice of the number of constraints to be used in the inversion procedure but it has to stay as close as possible to its initial value. We choose the RL that best agrees with independent estimations of different integrated transports through key sections of the SIO considered as references: the $30^{\circ} \mathrm{E}$ section $(143.7+/-4.7 \mathrm{~Sv}$ and $1.73+/-0.43 \mathrm{PW}$, Park et al. 1997), the $32^{\circ} \mathrm{S}$ section (-8.1+/-6.6 Sv and $-1.30+/-0.28 \mathrm{PW}$, Toole \& Warren, 1993) and the $130^{\circ} \mathrm{E}$ section (WOCE/SR3, 151 +/- $7 \mathrm{~Sv}$ and 1.73 +/- 0.43, Rintoul \& Bullister, 1999).

We compute the integrated heat and mass transport for key sections $30^{\circ} \mathrm{E}, 32^{\circ} \mathrm{S}, 120^{\circ} \mathrm{E}$ before inversion. The results are summarized in Table 1. For a RL between 2000 and $2500 \mathrm{~m}$, the zonal transport is small compared to the independent estimates. For a $5500 \mathrm{~m} \mathrm{RL}$, the transport is too large. The best choice is for a RL at $3500 \mathrm{~m}$ (or the deepest common level if shallower). The mean depth of the SIO is $3222 \mathrm{~m}$. A RL at $3500 \mathrm{~m}$ corresponds mainly to a $\mathrm{RL}$ placed at the deepest common level. In consequence, the bottom circulation and the velocity at the RL have very similar patterns.

In addition, it is interesting to note that before inversion the global mass imbalance and the transports at the key sections are drastically different but even after inversion some differences remain. This is in contrast to the results of Paillet and Mercier (1997) who found a lack of sensitivity to the choice of the RL in the North Eastern Atlantic Ocean. In the SIO, the meridional fluxes across $32^{\circ} \mathrm{S}$ are particularly sensitive to the choice of the RL. The meridional transport changes in sign between a $3000 \mathrm{~m} \mathrm{RL}$ and a $3500-\mathrm{m}$. This study shows that the model is still dependent on the first guess of the RL, due to a lack of initial information in particular data at the deep levels.

\section{III.3. Constraint contributions}

We used an incremental technique to evaluate the contribution of the different constraints. For this study the RL is fixed at $3500 \mathrm{~m}$ because it is the optimal level for the "a priori" circulation. The maps of the velocity at the RL and at the bottom are not shown but are discussed below.

Before inversion, mass conservation is not verified because it is not imposed by the dynamical method. The mass imbalance is $152 \mathrm{~Sv}$ for the whole SIO and a RL at $3500 \mathrm{~m}$. The mass conservation constraint is thus necessary and it is the first constraint to be applied. The mass conservation constraint improves the global mass conservation. The adjustment of the velocity at the RL with respect to mass conservation is most important in the vicinity of the ridges and the plateaux where the deep RL resulted in larger mass imbalances. The pattern of the estimated velocity at the RL corresponds to a barotropic correction. Before inversion, the

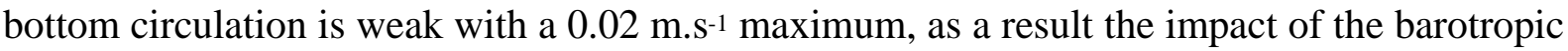
correction is important. The planetary vorticity conservation, which includes a condition on the bottom circulation due to the non-permeability condition, is now added. The abyssal circulation has thus to follow the topography. The addition of the planetary vorticity conservation constraint reorganizes the bottom motion along the isobaths with a cyclonic tendency in the Crozet, Madagascar and South Australian Basins with western boundary intensification (not shown). Under those two constraints, the meridional integrated transport through $32^{\circ} \mathrm{S}$ is $14 \mathrm{~Sv}$ northward. Addition of the top-to-bottom integrated heat flux conservation constraint forces a southward flux at $32^{\circ} \mathrm{S}$. Unless otherwise stated the discussion will focus on the inverse solution derived with the model set up as described 
above.

\section{III.4. General attributes of the inversion}

\section{III.4.1. Top-to-bottom integrated transport}

We define the total integrated transport by the sum of the geostrophic plus the Ekman transports. The top-to-bottom integrated transport is mapped in Fig. 5a before inversion and in Fig. 5b after inversion in the optimal configuration. The associated error map is presented in Fig. 5c. The Subtropical Gyre and the Antarctic Circumpolar Current are well defined in both cases and smoothed by the inversion. The estimated transport reveals strong topographic control north of the Crozet and Kerguelen plateaux. It also creates intensification and eastward extension of the subpolar Weddell Gyre. Those patterns are analyzed in Section V.

\section{III.4.2. Error map}

The inversion provides an error map (Fig. 5c) given the applied constraints. A large error means that the constraints or the data distribution are not enough to control the initial circulation. The meridional top to bottom integrated transport has errors between 0.5 and 7 $\mathrm{Sv}$, the zonal top to bottom integrated transport has errors between 0.6 and $7 \mathrm{~Sv}$. In both directions, the mean value for the error is $2.2 \mathrm{~Sv}$. The largest errors occur in the Mozambique Basin, the Agulhas Basin, the Crozet Basin and North of $20^{\circ} \mathrm{S}$.

\section{Analysis of the estimated circulation \\ IV.1. Integrated transport}

\section{IV.1.1. Analysis Tool - Stream function definition}

The inverse model provides corrected values for the density field and the velocity at the RL that conserve the integrated mass flux, the planetary vorticity balance and the integrated heat flux. Hence we can define the depth integrated stream function p based on the non-divergence of the mass transport such that:

$$
\mathrm{U}=(-\partial \mathrm{p} / \partial \mathrm{y}, \partial \mathrm{p} / \partial \mathrm{x})
$$

where $\mathrm{U}$ is the top to bottom integrated transport.

The stream function (Fig. 6) is an analysis tool that permits quantification of the topto-bottom integrated transports showing the main circulation pattern of the SIO. Three features emerge from this map. The Subtropical Gyre (STG) is enclosed within the $185 \mathrm{~Sv}$ isoline. The $160 \mathrm{~Sv}$ isoline in the north and the $0.1 \mathrm{~Sv}$ in the south limit the ACC. The Weddell Gyre is limited by the $-3 \mathrm{~Sv}$ isoline in the east. A detailed discussion of those patterns is now presented.

\section{IV.1.2. Diagnostics}

\section{IV.1.2.1. The Subtropical Gyre}

The STG is principally located in the Western half of the Indian Ocean. On Fig. 6 the stream function isolines are superimposed on the modelled topography to highlight the topographic control of the STG. The South East Indian Ridge limits the eastern extension of the gyre at $38^{\circ} \mathrm{S}-74^{\circ} \mathrm{E}$. However the $185 \mathrm{~Sv}$ isolines cross the ridge between $28^{\circ} \mathrm{S}$ and $23^{\circ} \mathrm{S}$ only to be blocked in part by the Ninety Ridge. The topography forces the separation of three small anticyclonic cells bounded by the 205Sv contour. Two $10 \mathrm{~Sv}$ cells lie east of Madagascar Ridge, the third, more intense (25Sv) cell lies between the Madagascar Ridge and South Africa close to the eastern margin of the coast (isoline 220 not shown in the Fig.6).

At the western margin of the STG, a strong transport (55 Sv southwards) is associated with the Agulhas Current (AC). This current retroflects eastward as the Agulhas Return Current (ARC) which is blocked by the Central Indian Ridge near $80^{\circ} \mathrm{E}$. The sources of the Agulhas transport can be split into $10 \mathrm{~Sv}$ from the Mozambique Channel, $5 \mathrm{~Sv}$ from the 
eastern margin of Madagascar, $15 \mathrm{~Sv}$ from the recirculation of the STG and $25 \mathrm{~Sv}$ from the Natal Valley recirculation.

Stramma and Lutjeharms (1997) define the eastern border of the STG by 65Sv balancing the AC transport and its southern border by $60 \mathrm{~Sv}$ transported by the ARC, supplying the anticyclonic gyre through several branches. Previous estimates of the transport associated with the AC range between 9 to $91 \mathrm{~Sv}$ depending on the choice of the RL to calculate it (Beal \& Bryden, 1999). Stramma and Lutjeharms (1997) geostrophically calculate $65 \mathrm{~Sv}$ transport. . Bryden and Beal (2001) estimate this transport from CTD measurements with additional LADCP data undertaken in the Natal Valley and West of the Mozambique Ridge (1995 and 1996 Discovery cruises). Beal and Bryden (1999) describe a V shape AC. Their direct measurement is $75 \mathrm{~Sv}$ and the geostrophic calculation is $73 \mathrm{~Sv}$, with a RL adjusted using the zero velocity given by the LADCP. This is $15 \mathrm{~Sv}$ less than the Toole and Warren (1993) estimate made from CTD measurements at $32^{\circ} \mathrm{S}$ in 1987 . The main reason for the discrepancy between those two estimates is the choice of the RL. For the inverse model the transport associated with the $\mathrm{AC}$ is small $\left(55 \mathrm{~Sv}\right.$ at $\left.32^{\circ} \mathrm{S}\right)$ because of a strong correction to the velocity at the RL after inversion in this region. Hence a strong Agulhas Undercurrent modulates the intensity of the AC. Such a feature has been observed in later studies (Donohue Beal \& Firing, 2000) and will be discussed later in the Section V.

\section{IV.1.2.2. The Antarctic Circumpolar Current}

The 160 and 0.1 isolines define the ACC (Fig. 6). At $20^{\circ} \mathrm{E}$, the ACC is an energetic eastward current with a meridional extent of about $1000 \mathrm{~km}$. The associated transport is 160 Sv. At that longitude, the intense ARC controls the ACC's northern extension. The Southwest Indian Ridge and the energetic subpolar gyre limit the ACC's southern extension. After crossing the Southwest Indian Ridge near $25^{\circ} \mathrm{E}$, the current spreads from the Agulhas Basin to the Weddell-Enderby Abyssal Plain. From $30^{\circ} \mathrm{E}$, the ACC splits into three branches. The first one flows north of the Crozet Plateau, the second between the Crozet Plateau and the Conrad Rise and the third continues south of the Conrad Rise.

The integrated transport associated with the first branch involves $75 \mathrm{~Sv}$ (isolines 160 and 85). On its way to the east, it trends northeast and joins the ARC. From this branch $15 \mathrm{~Sv}$ flows south of the Del Caño Rise and then up to the north of the Crozet Plateau flowing through a passage at $47^{\circ} \mathrm{E}-45^{\circ} \mathrm{S}$. Analysis of the SWINDEX cruise in 1995 reveals such a pathway (Pollard \& Read, 2001). Those data were not available for our study. In our case the adjustment of the velocity at the RL depends on the data set and the model's constraints. In Pollard and Read (2001) barotropic adjustments to geostrophic calculations were made using measurements from moorings and a ship mounted ADCP. The agreement on the pathways is a consequence of the potential vorticity conservation constraint, which controls mainly the adjusted velocity near the ridges.

The second branch of the ACC (between the 85 and $20 \mathrm{~Sv}$ isolines) flowing past the Crozet Plateau and the Conrad Rise, splits in 2 limbs. The first one oscillates north to south and transports 15 Sv north of Kerguelen Island. The inverse calculation allows 57\% of the ACC to go north of Kerguelen in agreement with Park and Gambéroni's (1995) results for the surface circulation. The second limb of this branch (between the 70 and 20 isolines) moves south of the Crozet Plateau for its northern limit (70 isoline) and south of the Conrad Rise for its southern limit (20 isoline). The 20 and 30 isolines then turn to the south under the impact of an eddy centred at $59^{\circ} \mathrm{E}-56^{\circ} \mathrm{S}$ (discussed later). The $50 \mathrm{~Sv}$ of this limb crosses the Kerguelen Plateau mostly south of Kerguelen Island with $10 \mathrm{~Sv}$ passing through the Fawn Trough.

The third branch of the ACC flows South of the Conrad Rise and transports 20Sv (between the 20 and the 0.1 isolines) to the east through the Princess Elizabeth Trough. 
Reaching the Australo-Antarctic Basin, this limb turns to the North. This feature corresponds to the Southern Front of the ACC defined by Orsi, Witworth and Nowlin (1995). This front is the southern boundary of the water masses whose temperature maximum is warmer than $1.8^{\circ} \mathrm{C}$. Such a feature has been observed during the SR3 cruise between Tasmania and Antarctica at $63^{\circ} \mathrm{S}$ and analysed by Rintoul and Bullister (1999). Despite the fact that the SR3 data are not incorporated into our data base, the inverse solution suggests a southward extension of the ACC which reaches the Antarctica's continental plateau east of the Kerguelen Plateau (the 0.1 isoline is located at $115^{\circ} \mathrm{E}-63^{\circ} \mathrm{S}$ ). At $120^{\circ} \mathrm{E}$, the meridional extension of the ACC is $19^{\circ}$ and $78 \%$ of the transport is between $47^{\circ} \mathrm{S}$ and $57^{\circ} \mathrm{S}$.

\section{IV.1.2.3 The Weddell Gyre}

After inversion a cyclonic circulation located south of the ACC in the western margin of the SIO emerges. This circulation is a consequence of the adjustment of the velocity at the $\mathrm{RL}$, which respects the conservation constraints for the depth integrated mass transport, the depth integrated heat transport and the potential vorticity balance at the RL. The Southern Front (indicated by the 0.1 isoline in Fig. 6) encloses this structure to the north and east. The southern border of the cyclonic gyre is the Antarctic continent. According to the model, the Southern Front is observed at $20^{\circ} \mathrm{E}-52^{\circ} \mathrm{S}$ and $30^{\circ} \mathrm{E}-58^{\circ} \mathrm{S}$. At $30^{\circ} \mathrm{E}$, the mean location between 1989 and 1994 of such a feature was $55^{\circ} \mathrm{S}$ (Schröder \& Fahrbach, 1999). This location defines the border between the ACC and the Weddell Gyre. After inversion, the Weddell Gyre transports $45 \mathrm{~Sv}$. Before inversion, only $0.1 \mathrm{~Sv}$ were transported by the Weddell Gyre and its eastern extension stopped at $26^{\circ} \mathrm{E}$. At the Greenwich Meridian Schröder and Fahrbach (1999) distinguished two limbs in the Weddell Gyre: the northern limb transports $61 \mathrm{~Sv}$, the southern one transports $66 \mathrm{~Sv}$. Their estimates are deduced from geostrophic calculation adjusted to LADCP measurements. Using the same calculation but with no LADCP adjustment, the Weddell Gyre transports at 30 $\mathrm{E}$ was16Sv during WOCE I6/CIVA 1 in 1993 and 14Sv during WOCE I6/CIVA 2 in 1996 (Park et al. 2001). As those data are incorporated in the inverse model, the discrepancy between the thermalwind estimate and the model confirms the important barotropic nature of the Weddell Gyre.

Many investigations such as iceberg tracking (Tchernia \& Jeannin, 1980), altimetry (Park \& Gamberoni, 1995) and studies conducted on the Polarstern between 1989 and 1996 (Schröder \& Fahrbach, 1999) note that classical hydrology cannot reveal the eastern extension of the Weddell Gyre (Gouretski \& Danilov, 1993 and 1994; Park, Charriaud, Craneguy \& Kartavtseff, 2001, for a review). The inverse model suggests an eastern extension of the Weddell Gyre beyond $40^{\circ} \mathrm{E}$, but this is not well defined. Gouretski and Danilov $(1993,1994)$ as well as Schröder and Fahrbach (1999) observed an unstable zone between the Weddell Gyre and the Southern Front. In the inverse model this zone is particularly complex with many eddies involving less than 5Sv. This border zone is thus favourable for water mass mixing. The quantification of the Weddell Gyre, its barotropic nature and its eastern extension is one of the main insights of this inversion.

\section{IV.1.3. Discussion}

\section{IV.1.3.1. Is the non-synopticity of the data set a problem?}

At $56^{\circ} \mathrm{S}, 59^{\circ} \mathrm{E}$ there is a large eddy, which is not smoothed out after inversion (fig $5 \mathrm{~b}$ ). This feature is linked to a unique profile sampled on 10 April 1970. The hydrological characteristics of this station fit with water masses originating from the north of its actual position. Is the position an error? To answer this question, we extracted all the profiles sampled during this cruise but found no other anomalies. Around this date, any positional error would not explain the anomalous profile because the ship's route did not go where the profile characteristics would normally be found. No topographic anomaly can explain such a 
feature. We conclude that the profile represents a real feature but no conclusion on its permanency can be drawn. The lack of data around the position prevents any answer. The data sampled for the inverse model were collected between 1903 an 1996 but in this region the majority of locations were sampled only once. Further measurements in this region have to be proposed to avoid the ambiguity. The inverse model is constrained to stay close to the initial data field and the density is adjusted in the range of the covariance error matrices based on the spatial correlation. The conclusion is thus that the inverse model is very sensitive to a lack of data.

Such a point is particularly problematic in regions where important variability occurs such as in the Mozambique Channel. The inverse model suggests that 10Sv cross the Mozambique Channel to supply the Agulhas Current through a complex circulation. In a recent paper, Donohue and Toole (2003) estimate 17 Sv. We cannot determine here the nature of the supply to the Agulhas Current, whether it is a regular current or an accumulation of small anticyclonic cells, because the inverse model estimate is based on historical hydrographic profiles. During the ANTARES 2 cruise, Park and Gambéroni (1997) observed major variability in the Crozet Basin proving AAIW injection. Gouretski and Danilov (1993, 1994) describe energetic mesoscale activity at the eastern boundary of the Weddell gyre. The STG is an area with one of the highest estimates of mesoscale variability in the world ocean as deduced from drifting buoys (Daniault \& Ménard, 1985) and sea surface temperature (Lutjeharms \& van Ballegooyen, 1988). This is confirmed by altimeter results (Cheney, Marsh \& Beckly, 1983; Gründlhing, Carter \& Stanton, 1991; Feron, de Ruijter \& Oskam, 1992; Park \& Gambéroni 1995). A study of the Agulhas Return Current (Lutjeharms \& Ansorge, 2001), made from CTD and XBT analyses points out the correlation between the extent and the location of the ARC, and its high mesoscale variability. Lutjeharms and Ansorge (2001) limited the eastern extension of the ARC to $66^{\circ} \mathrm{E}$ to $70^{\circ} \mathrm{E}$, proposing to call the residual transports east of this location the South Indian Current. The proximity of the ARC (SIC) and the STF (called STC by the authors) causes an increase in horizontal shear and instability. The estimated circulation by the inverse model suggests a boundary for the ARC further to the east, which fits with the Central Indian Ridge.

\section{IV.1.3.2. Topographic control}

Obviously the inverse model cannot resolve the time variability of the SIO circulation. The addition of dynamical constraints in the inverse model reveals major topographic control for the ACC and the STG. The ACC divides into several branches, which split and recombine depending on the topography (Pollard Lucas \& Read 2002). The inverse model is able to reproduce topographic control mainly through the potential vorticity conservation constraint. Lutjeharms and Valentine (1984) for the STG, Gouretski and Danilov for the Weddell Gyre (1993, 1994) and Craneguy and Park (1999) for the ACC proposed a dynamic explanation of this process using a jet model. The inertial jet model is a tool to distinguish the topographic effect from the $\beta$ effect (Coriolis parameter's derivative with latitude). The predominant effect depends on the initial conditions of the jet: its mean velocity and its initial depth. The result is that for sufficient bottom velocity (e.g. 0.02 to $0.04 \mathrm{~m} / \mathrm{s}$ ), the topographic effect dominates. If the bottom velocity is not zero, the current moves to the north (south) if the initial depth of the jet is deeper (shallower) than the local depth. Near the Crozet Plateau, the limbs of the ACC move to the north where the depth is shallower and to the South in the deep Weddell-Enderby Basin. The potential vorticity conservation constraint in the inverse model thus simulates a balance between the topographic effect and the $\beta$ effect.

\section{IV.1.3.3. Are the fronts and transports linked north of Kerguelen}

We now discuss the position of the Polar Front (PF) and the ACC transports estimated 
by the inverse model. The PF is defined by the $2^{\circ} \mathrm{C}$ isotherm (the southernmost bold dark grey line on Fig. 6) at 200m (Belkin \& Gordon, 1996, for a review; Pollard et al 2002 for a review of the southern ocean zonation). The location of the PF is deduced after objective analysis of the historical temperature field. There is no correction after inversion. The position of the PF is north of Kerguelen. It is clear that in our case the core of the ACC transport and hydrological definition of the PF do not match. The inverse model reaches thus the same conclusion as Pollard et al (2002) who showed that the PF defined by subsurface $2^{\circ} \mathrm{C}$ minimum was not a major transport feature in this region. From previous studies (Rintoul \& Bullister, 1999, Pollard et al, 2001), the challenge is to be able to locate precisely and easily the branches of the ACC avoiding confusion caused by the definition of the fronts.

\section{IV.2. The abyssal circulation}

After barotropic adjustment, the bottom circulation is zero neither in the abyssal plains nor in the quite homogenous Antarctic Zone. The pattern of the abyssal velocity (Fig 7) is complex.

Our actual knowledge of the bottom circulation of the SIO is based on bottom and deep water mass analysis (Rodman \& Gordon 1982, Mantyla \& Reid, 1995). The inverse model proposes a global pattern strongly influenced by the distribution of the few deep samples and the constraint adjustment.

The bottom transport entering the Mozambique Basin is estimated to be $3.6 \mathrm{~Sv}$ northward. Previous estimates, according to Read and Pollard (1999), are 0.5 to $1.6 \mathrm{~Sv}$. The discrepancy results from the large barotropic correction to the velocity at the RL after inversion.

The bottom circulation after inversion is cyclonic in the Crozet Basin and extends to the Madagascar Basin. The western part of this cell is a deep western boundary current composed of bottom water masses from the Mozambique and Weddell-Enderby Basins. At $57^{\circ} \mathrm{E}$, the flow crosses the Central Indian Ridge (Atlantis II Fracture Zone, Warren 1982).

The map of the integrated deep (bottom to 2000m) transport also indicates many eddies near the Central Indian ridge (Fig. 10). Such a circulation can be associated with a mixing zone between different sources of deep waters (CDW, NADW, and NIDW). East of the Crozet Basin, along the Central Indian Ridge, the transport is southward, transporting the NIDW observed during the SUZIL cruise (Park et al. 1993). According to the inverse estimation, the bottom transport in the Crozet Basin comes mainly from the AustralianAntarctic Basin flowing between the Kergelen Plateau and the Southeast Indian Ridge. This is a consequence of the westward adjustment of the velocity at the RL.

The general pattern of the bottom circulation is in good agreement with water mass analysis southeast of the Kerguelen Plateau (Mantyla \& Reid, 1995). The large-scale pattern has a cyclonic tendency and is very complex. The Western Boundary Current in the Crozet basin is moving northward in the Indian Ocean. An important Agulhas Undercurrent exists.

The SIO bottom circulation after inversion is mainly fed by bottom water from the Australian-Antarctic Basin, which has not been observed west of the Kerguelen Plateau. The majority of the flow which crosses the Kerguelen Gap is northward, as observed during the ADOX cruise (Haine et al.,1998). No conclusion is possible on the origin of the bottom water masses involved. Generally, the Kerguelen Gap is considered as the main access for the bottom waters from the Enderby Basin into the Crozet Basin (Jacobs \& Georgi, 1977; Mantyla \& Reid, 1995). Bottom transport is estimated to be 0.8 to $1.6 \mathrm{~Sv}$ by Haine et al (1998). The authors argue a Weddell-Enderby origin. Even if the characteristics of the AABW in the Kerguelen Gap are measurably different from the Weddell Sea Bottom Water, Haine et al link this discrepancy with large diffusivity and dilution of the WSBW on its way to the 
Kerguelen Gap. The inverse model suggests an Australian-Antarctic origin but we cannot confirm this from synoptic observations.

\section{IV.3.The meridional overturning circulation IV.3.1. Issue}

The Eurasian continent constraints the meridional circulation for both atmosphere and ocean. In the annual mean, the Indian Ocean gains heat from the atmosphere (Hsiung, 1985; Oberhüber, 1988). To avoid accumulation, the net heat must be transported south. Indeed the northward flowing cold waters of southern origin replace the warm surface water moving south. This is called the Meridional Overturning Circulation (MOC). There is still no consensus on the intensity, nor on the vertical structure of the MOC. In the SIO an intense MOC at deep levels is observed but not reproduced by primitive equation models. We present here the first attempt to evaluate the MOC from a finite difference inverse model which combines observations and dynamics.

Recent studies that have investigated the MOC in the Indian Ocean can be divided into two groups following the evolution of the physical oceanography over the last decade.

The first group compares model simulations and observations. OGCMs estimate a weak, deep overturning (Semtner \& Chervin, 1992; Wacogne \& Pacanowski, 1996; Garternicht \& Schott, 1997; Lee \& Marotzke, 1997; Zhang \& Marotzke, 1999 and Table 2 for a review). Lee \& Marotzke (1997) determine a northward 14 Sv meridional flux in the upper $1000 \mathrm{~m}$ at $32^{\circ} \mathrm{S}$ from the GFDL model (Cox, 1984) combined with an adjoint for consistency with the Levitus climatology (Levitus et al. 1994). Those models are limited by poor sub-grid-scale parameterizations creating model errors, limited resolution of the bottom circulation, smoothed climatologies lacking error estimates and a lack of observations compared to other oceans. Nevertheless, OGCMs raise the question of the processes involved in the MOC: advection and/or diffusivity. Because these estimates relate to the upper 1000 meters, the influence of surface and subsurface features including wind, heat and freshwater fluxes but also the Indonesian Throughflow on the MOC have to be investigated.

Another approach is based on observations only. The MOC in the Indian Ocean has been estimated using classical geostrophic calculation based on hydrographic data at $18^{\circ} \mathrm{S}$ (Warren, 1981b) and at 32 ${ }^{\circ} \mathrm{S}$ (Toole \& Warren, 1993). The problem is then the choice of the level of no motion to calculate the absolute velocity of the water column. The MOC in the Indian Ocean is located deeper than $1000 \mathrm{~m}$ and has a range between 19 and $27 \mathrm{~Sv}$.

Within the WOCE period, box inverse modeling began to synthesize different transoceanic sections as they became available. As a result many studies estimate the MOC in the Indian Ocean using new hydrographic data and new inverse box models. Estimates result in northward meridional transport from 10 to $16 \mathrm{~Sv}$ located below 1000 to $2000 \mathrm{~m}$ (MacDonald \& Wunsch, 1996; Robbins \& Toole, 1997; MacDonald, 1998; Ganachaud et al., 2000; Sloyan \& Rintoul, 2001). The estimates differ in the choice of hydrographic sections, additional constraints like silicate for Robbins and Toole (1997), new codes using new control parameters that penalize each constraint and the use of new WOCE data (Ganachaud et al., 2000). The present work uses a finite difference inverse model to evaluate the MOC in the Indian Ocean. This type of inverse model allows data analyses which use not only transoceanic lines (like the box inverse models) but also historical data with an estimation of the errors based on the spatial distribution of the measurements (section I).

\section{IV.3.2. Indonesian Throughflow estimation}

Obviously, the MOC depends on the different sources of heat that can feed the Indian 
Ocean. One of these is the Indonesian Throughflow (ITF). As the 3-D velocity and density fields available after inversion allow us to estimate transport, the first step is to discuss the ITF given by our model.

For each latitude, we compute the top-to-bottom and west to east integrated transport after inversion in the coast to coast box defined by $20^{\circ} \mathrm{E}-120^{\circ} \mathrm{E}$ and $10^{\circ} \mathrm{S}-34^{\circ} \mathrm{S}$. North of $18^{\circ} \mathrm{S}$ no coast to coast mass conservation can be used and we chose to leave this border open in order to evaluate the information given by the observations and the dynamical constraints. Table 3 displays the results and the associated errors. The meridional transport is around -1.7 $\mathrm{Sv}$ and is almost conserved between $32^{\circ} \mathrm{S}$ and $18^{\circ} \mathrm{S}$. At $10^{\circ} \mathrm{S}$ and $11^{\circ} \mathrm{S}$, the estimated meridional transport decreases from $49 \mathrm{~Sv}$ to $35 \mathrm{~Sv}$ respectively to the south. The ITF deduced from direct estimation across the Indonesian Passage after inversion is 39Sv eastward. During JADE (Fieux et al., 1994; Fieux, Molcard \& Ilahude,1996, data incorporated in the inverse model), the ITF is $2.6 \pm 9 \mathrm{~Sv}$ mean eastward flow (JADE2 cruise, in February 1992) and 18 $\pm 7 \mathrm{~Sv}$ mean westward flow (JADE1 cruise, in August 1989). The inverse estimate is thus doubtful due to a boundary problem exemplified by the maximum error zone (fig 5c). To conclude, the initial data and thus the constraints used in this inverse model are not sufficient to represent properly the circulation north of $18^{\circ} \mathrm{S}$ and the ITF. As in previous box inverse models, which also meet this problem, the first idea is to impose the ITF. What value is to be imposed? Has it to be depth dependent? Using a box inverse model, MacDonald (1998) imposed successively 0, 5 and $10 \mathrm{~Sv}$ westward for the top-to-bottom integrated transport crossing the Indonesian Passage. MacDonald could not conclusively determine the intensity of the ITF because the error bar was the same size as the estimate. Incorporating new data and new box inverse code, Ganachaud et al. (2000) reached the same conclusion. The most recent estimates for the ITF, from the first years of the International Nusantara Stratification and Transport (INSTANT) data using mooring deployments, give a range to $10 \pm 5 \times 10^{6} \mathrm{~m}^{3} / \mathrm{sec}$ westward with large seasonal and intraseasonal variability (Gordon et al. 2006).

Finally, the estimate of the ITF given by the present inverse model configuration can only be evaluated indirectly from net coast to coast mass transport south of $18^{\circ} \mathrm{S}$. The resulting ITF is $1.5 \pm 1 \mathrm{~Sv}$. Thus the finite difference model reaches the same conclusion as box inverse models: the top-to-bottom integrated transport associated with the ITF is negligible. As a result we will focus on quantification of the MOC south of $18^{\circ} \mathrm{S}$.

\section{IV.3.3. Quantification of the MOC \\ IV.3.3.1. Mean value and location}

The stream function displayed in Fig. 8 represents the cumulative zonally integrated transport in Sverdrup per hundred metres. From $18^{\circ} \mathrm{S}$ to $25^{\circ} \mathrm{S}$, the upper water masses flow northward. At $26^{\circ} \mathrm{S}$, the flow is southward for the six first levels $(10 \mathrm{~m}$ to $150 \mathrm{~m})$. Water between $150 \mathrm{~m}$ and $2500 \mathrm{~m}$ moves northward. Between $26^{\circ} \mathrm{S}$ and $29^{\circ} \mathrm{S}$, the depth of the southward flow increases reaching $1400 \mathrm{~m}$ at $30^{\circ} \mathrm{S}$.

The mean value for this meridional thermohaline recirculation is $8.8 \pm 4.4 \mathrm{~Sv}$ between $26^{\circ} \mathrm{S}$ and $32^{\circ} \mathrm{S}$. These results are compared to previous estimates in Table 2 . As in box inverse model calculations (Robbins \& Toole, 1997; Ganachaud et al., 2000), the MOC involves the deep layers (1400 $\mathrm{m}$ here). The associated deep water upwelling takes place between $26^{\circ} \mathrm{S}$ and $32^{\circ} \mathrm{S}$.

\section{IV.3.3.2. Induced vertical velocity}

The finite difference inverse estimate of the MOC allows calculation of the induced vertical velocity. It is calculated in the coast to coast box defined by $35^{\circ} \mathrm{E}-120^{\circ} \mathrm{E}$ and $26^{\circ} \mathrm{S}-$ $32^{\circ} \mathrm{S}$. The mean upwelling is $15.8 \times 10^{-5} \pm 8 . \times 10^{-5} \mathrm{~cm} / \mathrm{s}$. At $32^{\circ} \mathrm{S}$ it increases to $26 . \times 10^{-5}$ 
$\mathrm{cm} / \mathrm{s}$. We compile in Table 4 the vertical velocities previously reviewed by Read and Pollard (1999). The inverse estimate belongs in the highest range and is close to the velocity observed in the Mozambique Basin by Toole and Warren (1993) and more recently using both CTD (adjusted to ADCP) and mooring data during SWINDEX (Read \& Pollard, 1999). While Read and Pollard were not convinced of the intensity of the vertical motion, they suggested that a large barotropic current increases the vertical velocity measurably. In our case the barotropic adjustment needed to satisfy the model constraints involves a large velocity at the RL that intensifies the MOC and thus the vertical velocity.

The MOC is estimated and located in the Subtropical Zone. The intense vertical velocity has a value close to those observed in the Mozambique Basin. The next issue is to locate the MOC zonally.

\section{IV.3.4. Meridional transport across $32^{\circ} \mathrm{S}$}

The $32^{\circ} \mathrm{S}$ section was sampled before WOCE (Charles Darwin cruise, 1987, Toole \& Warren, 1993) and has been exploited ever since in a wide range of studies. For the present work, we refer to the study of Robbins and Toole (1997, RT97) and Ganachaud et al. (2000, G00). In both cases a box inverse model was used to investigate the $32^{\circ} \mathrm{S}$ section. Fig. 9 shows integrated transports above $2000 \mathrm{~m}$ (to the surface) and below $2000 \mathrm{~m}$ (to the bottom) together with comparisons with previous estimates. The 14.4 Sv net deep meridional transport after inversion is the same order as the $12 \pm 3 \mathrm{~Sv}$ estimated by RT97 and the $10.6 \pm 4 \mathrm{~Sv}$ estimated by G00. However, the zonal repartition of the deep meridional transport differs drastically. According to the inversion, the majority of the deep meridional transport at $32^{\circ} \mathrm{S}$ is located between the African coast and the Madagascar Ridge $\left(45.2^{\circ} \mathrm{E}\right)$. This feature corresponds to the Agulhas Undercurrent discussed later. In the Crozet Basin, the deep meridional transport moves northward as G00 (6.7 Sv in G00 and 1.1 Sv after inversion). RT97 found 1.6 Sv southward caused by a large cyclonic structure centred at $60^{\circ} \mathrm{E}$ in the Crozet Basin. For G00 the northward 6.7 Sv found in the Crozet Basin comes from the Kerguelen Gap and limits the cyclonic eddy observed by RT97.

The MOC estimated here involves deep and bottom water masses. Almost all the deep meridional transport at $32^{\circ} \mathrm{S}$ is located west of the Madagascar Ridge. West of the Mozambique Ridge ( $36^{\circ} \mathrm{E}$ ), $11 \mathrm{~Sv}$ move northward in the deep layers for an Agulhas Current top-to-bottom integrated transport of $55 \mathrm{~Sv}$ at the lower end of available estimates.

\section{IV.3.5. The MOC and the Agulhas System}

\section{IV.3.5.1. The MOC and the Agulhas Undercurrent}

Almost all the meridional transport is located west of the Mozambique Ridge at $32^{\circ} \mathrm{S}$. The adjustment of the velocity at the RL to satisfy the inverse model constraints creates a large undercurrent below the V shaped Agulhas Current. This feature was observed by Beal and Bryden (1999) and is called the Agulhas Undercurrent. The undercurrent does not exist before inversion. It appears with a small intensity as soon as mass conservation is added to constraint the model. The addition of the potential vorticity conservation constraint controls its connection to the bottom topography. The heat flux conservation constraint increases its intensity. Each of the three dynamical constraints of the inverse model plays a role in the emergence of such a feature.

Bryden and Beal (2001) explored the influence of the Agulhas Current on the intensity of the MOC by reanalysing the $32^{\circ} \mathrm{S}$ section. Using geostrophic calculation, they adjusted the velocity at the RL near the Broken Plateau close to Australia. They exploited new CTD and LADCP measurements from the Natal Valley and west of the Mozambique Ridge (1995 and 1996, Discovery cruises). One of the insights of this study is that the intensity of the Agulhas 
Current plays a major role in the intensity and the zonal repartition of the meridional transport on each side of the Mozambique Ridge. A large Agulhas Current (84.6 Sv southward), induces a 1.4 Sv northward deep meridional transport in the Natal Valley, and 23.5 Sv for the rest of the $32^{\circ} \mathrm{S}$ section. A $66.3 \mathrm{~Sv}$ Agulhas Current induces $6.1 \mathrm{~Sv}$ in the Natal Valley and 14 Sv east of it. Finally for a weak 55 Sv Agulhas Current, the majority of the MOC can be associated with northward NADW crossing the Natal Valley in the Agulhas Undercurrent. The corresponding meridional transport is 9.7 Sv west of the Mozambique Ridge and $8.9 \mathrm{~Sv}$ for the rest of the section. The adjustment to the LADCP data sampled in 1996 matches the weak estimation of the Agulhas Current. In our database we use the WOCEI6/CIVA2 data also sampled in 1996. The same estimate of the transport associated with the Agulhas Current in both cases raises the question: Was it a year with a weak Agulhas Current? With the data base used, the inverse model is not able to answer this question.

The meridional transport carried by the Agulhas Undercurrent is 11 Sv northward after inversion. The rest of the meridional transport comprises $3.4 \mathrm{~Sv}$ and flows northward on the western margin of the ridges.

\section{IV.3.5.2. The MOC and heat fluxes}

The net meridional heat flux represents $-0.53 \mathrm{PW}$ at $18^{\circ} \mathrm{S}$ and $-0.33 \mathrm{PW}$ at $32^{\circ} \mathrm{S}$. Following the normal convention the negative values correspond to southward transports. Those values are small compared to previous estimates presented in Table 2. The meridional heat flux is found in the upper $2000 \mathrm{~m}$. It is concentrated west of Madagascar in two lobes, which fit the two main anticyclonic features observed in the Subtropical Gyre (Fig. 6). Almost all the meridional transport is confined to the western margin of the Mozambique Ridge. Hence the intensity of the meridional heat flux is linked to the intensity of the Agulhas Current carrying warm waters. 


\section{Conclusion and prospects}

The optimal configuration of the finite difference inverse model elaborated in the first four sections was applied to synthesise and analyse the large-scale South Indian Ocean Circulation. The Subtropical Gyre includes anticyclonic structures trapped by the complex bottom topography of the SIO. The Agulhas Current forming the western margin of the STG transports $55 \mathrm{~Sv}$. The closing limb of the STG and many small-scale features crossing both the Mozambique Channel and the East Side of Madagascar all supply the Agulhas Current. The majority of the ACC flows north of Kerguelen. The ACC transports 160Sv in many branches with variable meridional extent depending on topographic control that is well parameterised by the potential vorticity conservation constraint. The southern extension of the ACC carries $20 \mathrm{~Sv}$ and reaches the margin of the Antarctic Shelf near the Kerguelen Plateau. The adjustment of the velocity at the RL estimates the barotropic component of the absolute geostrophic flow. Hence the cyclonic Weddell Gyre transports $45 \mathrm{~Sv}$ and its barotropic nature is demonstrated. The eastern extension of the Weddell Gyre depends on the dynamic constraints in the southern branch of the ACC. Another barotropic feature which emerges after the inversion is the Agulhas Undercurrent flowing beneath the V-shaped Agulhas Current.

The Indonesian Through Flow transports $1.5 \pm 1 \mathrm{~Sv}$ in the coast to coast box between $18^{\circ} \mathrm{S}$ and $32^{\circ} \mathrm{S}$.

The MOC is found between $26^{\circ} \mathrm{S}$ and $32^{\circ} \mathrm{S}$. It is a deep overturning with a zero crossing at $1400 \mathrm{~m}$ and mean magnitude $8.8 \pm 4 \mathrm{~Sv}$. The associated vertical velocity is large, $15.8 \pm 8 \times 10^{-5} \mathrm{~cm} / \mathrm{s}$. At $32^{\circ} \mathrm{S}$, the meridional transport is $14.4 \mathrm{~Sv}$ flowing northward below $1400 \mathrm{~m}$. The majority of the transport is trapped in the Natal valley and is associated with a large Agulhas Undercurrent (15 Sv). The associated heat flux is $-0.33 \mathrm{PW}$. The inverse model suggests a link between the value of the transport of the Agulhas Current and the intensity of the MOC and its zonal location. The association of a weak Agulhas Current transporting warm waters and the huge upwelling associated with cold waters explains the small meridional heat gain.

The inverse model analysis identifies persistent features in the SIO. The large errors in the Tropical Zone and the trapped MOC west of the Mozambique Ridge suggest not only that the model is somehow underconstrained mainly by the non synopticity and the undersampling of the deep layers but also indicate new avenues for research. The influence of the Agulhas System and the MOC on the meridional heat gain has to be studied. The problem raised by the non synopticity of the initial data set can be avoided by using additional terms in the spatial correlation function during the Objective Analysis procedure and/or can be limited by changing the weight covariance matrices in the cost function.

The finite difference inverse model provides a synthesis of the South Indian Ocean. The analysis provides new insights and avenues for further studies. Many WOCE sections have become available since this work was undertaken. New types of measurement are emerging such as LADCPs and arrays of floats. New data assimilation techniques are being developed. Box inverse models are becoming more complex with additional diapycnal mixing terms. New altimetric observations such as seawater colour sensors and the Jason altimeter are becoming available. The synthesis of all these different sources of information is still an inverse problem.

Acknowledgements: The authors are grateful to Dr. Y. H. Park who initiated the first part of 
this study. All calculations were made with the computer resources of the Institut De Recherche en Informatique Scientifique (IDRIS) of the Centre National de Recherches Scientifiques (CNRS) based at Orsay on their Cray C94-98 super-calculator. The authors are particularly grateful to the assistant team of IDRIS without whose efficient help this work would not have been achieved.

\section{References}

Beal, L.M. \& Bryden H.L., (1997) Observations of an Agulhas Undercurrent. Deep-Sea Research I 44, 1715-1724.

Beal, L. M., \& Bryden H. L., (1999) The velocity and vorticity structure of the Agulhas Current at $32^{\circ}$ S, Journal of Geophysical Research, 104, 5151-5176.

Belkin I.M. \& Gordon A.L., (1996) Southern Ocean fronts from the Greenwich Meridian to Tasmania. Journal of Geophysical Research 101, 3675-3696.

Bretherton, F.P., Davis R.E. \& Fandry C.B., (1976) A technique for objective analysts and design of oceanographic experiments applied to MODE-73. Deep-Sea Research 23 , 559581.

Bryden, H.L. \& Beal L.M., (2001) Role of the Agulhas Current in Indian Ocean circulation and associated heat and freshwater fluxes. Deep-Sea Research I 48, 1821-1845.

Carmack, E.C., (1977) Water characteristics of the Southern Ocean south of the Polar Front. In: Angel, M., Editor, , 1977. A Voyage of Discovery, George Deacon 70th Anniversary Volume, Pergamon Press, Oxford, 15-41.

Cheney, R.E., Marsh J.G., \& Beckly B.D., (1983) Global Mesoscale Variability from Collinear Tracks of SEASAT Altimeter Data, Journal of Geophysical Research, 88, 43314341

Cox, M. D., (1984) A primitive equation, 3-dimensional model of the ocean. Ocean Group Tech., Rapport I : Fluid Dyn. Lab. / Princeton, N. J.

Craneguy, P. \&. Park Y. H, (1999) Controle topographique du courant circumpolaire antarctique dans l'ocean Indien sud. Comptes Rendus de l'Academie des Sciences, Serie II. France, Gauthier-Villars. Montrouge France. 1999. Sciences de la Terre et des Planetes. 328: 583-589

Daniault, N. \& Menard Y, (1985) Eddy Kinetic Energy Distribution in the Southern Ocean from Altimetry and FGGE Drifting Buoys, Journal of Geophysical Research,90, 11 877-11 889

Donohue, K.A., Beal L.M. \& Firing E., (2000) Comparison of three velocity sections of the Agulhas Current and Agulhas Undercurrent. Journal of Geophysical Research 105, 2858528593.

Donohue, K.A. \& Toole J.M., (2003) A near-synoptic survey of the southwest Indian Ocean. Deep-Sea Research II 50, 1893-1931. 
Feron, R.C.V., de Ruijter W.P.M. \& Oskam D., (1992) Ring-shedding in the Agulhas Current System. Journal of Geophysical Research 97, 9467-9477.

Fieux, M., Andrié C., Delecluse P., Ilahude A.G., Kartavtseff A., Mantisi F., Molcard R. \& Swallow J.C., (1994) Measurements within the Pacific-Indian Oceans Throughflow region. Deep-Sea Research I 41, 1091-1130.

Fieux M., R. Molcard \&. Ilahude A.G, (1996) Geostrophic transport of the Pacific-Indian oceans throughflow. Journal of Geophysical Research 101, 12421-12432.

Ffield, A., Toole J., \& Wilson D., (1997) Seasonal circulation in the South Indian Ocean. Geophysical Research Letters, 24, 2773-2776.

Fu, L.-L., (1986) Mass, heat and freshwater fluxes in the South Indian Ocean. Journal of Physical Oceanography 16, 1683-1693.

Fukumori, I. and Wunsch C., (1991) Efficient representation of the North Atlantic hydrographic and chemical distributions. Progress in Oceanography $27,111-195$.

Ganachaud, A., Wunsch C., Marotzke J., \& Toole J., (2000) Meridional overturning and large-scale circulation of the Indian Ocean, Journal of Geophysical Research, 105, 26,11726,134 .

Garternicht, U. \& Schott, F., (1997) Heat fluxes of the Indian Ocean from a global eddyresolving model. Journal of Geophysical Research 102, 21,147-21,159.

Gordon A., Seosilo I., Brodjonegoro I., Ffield A, Jaya I., Molcard R., Sprintall J., Susanto R. D., van Akens H., Wijffels S., Wirasantosa S., (2006) The first 1.5 years of INSTANT data reveal the complexitles of the Indonesian Throughflow, CLIVAR Exchanges, Volume 11, ${ }^{\circ} 4$ $10-11$.

Gouretski V. V. \& Danilov A. I., (1993) Weddell Gyre: structure of the eastern boundary Deep Sea Research Part I: Oceanographic Research Papers, 40, 561-582

Gouretski V. V. and Danilov A. I., (1994) Characteristics of warm rings in the African sector of the Antarctic Circumpolar Current, Deep Sea Research Part I: Oceanographic Research Papers, 41, 1131-1157

Gründling, M.L., Carter R.A. \& Stanton R.C., (1991) Circulation and water properties of the southwest Indian Ocean, spring 1987. Progress in Oceanography 28, 305-342.

Haine, T. W. N., Watson A. J., Liddicoat M. I., \& Dickson R. R., (1998) The flow of Antarctic bottom water to the southwest Indian Ocean estimated using CFCs, Journal of Geophysical Research, 103, 27,637-27,654.

Heywood, K.J. , Sparrow M.D., Brown J. \& Dickson R.R., (1999) Frontal structure and Antarctic Bottom Water flow through the Princess Elizabeth Trough, Antarctica, Deep-Sea Research I, 46, 1181-1200 
Hsiung, J., (1985) Estimates of global oceanic meridional heat transport. Journal of Physical Oceanography, 15, 1405-1413.

Jacobs, S. S. \& Georgi D. T., (1977) Observations on the southwest Indian/Antarctic Ocean. A Voyage of Discovery. George Deacon $70^{\text {th }}$ Anniversary, Vol. Suppl. To Deep-Sea Research, 24, 43-84.

Jamous, D., (1991) Circulation générale et traceurs : Etude de l’Océan Indien Ouest. PhD, Université Pierre et Marie Curie - Paris VI, Paris, Fr.

Larqué, L., (1996) Etude des masses d'eau en Atlantique Sud et de la circulation océanique à grande échelle dans le bassin argenin. PhD, Université Paul Sabatier Toulouse, Fr.

Lee, T., \& Marotzke J., (1997) Inferring meridional mass and heat transports of the Indian Ocean by fitting a general circulation model to climatological data, Journal of Geophysical Research, 102, 10,585-10,602.

Levitus, S., (1982) Climatological atlas of the world ocean, NOAA Prof. Pap. 13, 173 pp., U.S. Govt. Print. Off., Washington, D.C.

Levitus, S., Burgett R. \& Boyer T., (1994) World Ocean Atlas 1994. Vol. 3, Salinity. Vol. 4, Temperature. NOAA Atlas NESDIS 3 \& 4, US Department of Communication, Washington, DC.

Lutjeharms, J. R. E. \& Valentine, H. R. (1984) Southern Ocean thermal fronts south of Africa. Deep-Sea Research, 12, 1461-1475.

Lutjeharms, J.R.E \& Van Ballegooyen R.C., (1988) The Retroflection of the Agulhas Current. Journal of Physical Oceanography, 18, 11, 1570-1583

Lutjeharms, J. R. E. \& Ansorge, I. J., (2001) The Aguhlas Return Current, Journal of Marine Systems, 30, 115-138.

Maamaatuaiahutapu, K., (1994), Etude de la circulation dans la région de Confluence des courants du Brésil et des Malouines. PhD, Université Paul Sabatier, Toulouse, Fr.

Macdonald, A. \& Wunsch C., (1996) A global estimate of the ocean circulation and heat fluxes. Nature, 382, 436-439

Macdonald, A, (1998) The global ocean circulation: a hydrographic estimate and regional analysis. Progress In Oceanography, 41, 281-382

Mantyla, A.W. \& Reid J.L., (1995) On the origins of deep and bottom waters of the Indian Ocean. Geophysical Research Letters 100, 2417-2439.

Marotzke, J., \& Willebrand J., (1996) The North Atlantic mean circulation: Combining data and dynamics. In: The Warmwatersphere of the North Atlantic Ocean, W. Krauss, ed., 55-90.

Mercier, H., M. Ollitrault and P.Y. Le Traon (1993), An inverse model of the North Atlantic general circulation using Lagrangian float data. Journal of Physical Oceanography 23, 689- 
715.

Oberhüber, J. M., (1988), An Atlas based on the COADS Data Set : the budgets of heat, buoyancy and turbulent kinetic energy at the surface of the global ocean, Max-Plank-Inst. Für Meteorology, Hamburg, Germany.

Orsi, A.H., Withworth III T. \& Nowlin W.D., (1995) On the meridional extent and fronts in the Antarctic circumpolar current. Deep-Sea Research I 42, 641-673.

Paillet, J. \& H. Mercier, (1997) An inverse model of the eastern North Atlantic general circulation and thermocline ventilation, Deep-Sea Research I 44 , 1293-1328.

Park, Y.-H., Gamberoni, L. \& Charriaud E., (1993) Frontal structure, water masses, and circulation in the Crozet Basin. Journal of Geophysical Research 98, 12361-12385.

Park, Y., \& Gambéroni L., (1995) Large-scale circulation and its variability in the south Indian Ocean from TOPEX/POSEIDON altimetry, Journal of Geophysical Research, 100, 24,911-24,930.

Park, Y. H. \& Gambéroni L., (1997) Cross-frontal exchange of Antarctic Intermediate Water and Antarctic Bottom Water in the Crozet Basin. Deep-Sea Research, 44, 963-986.

Park, Y.H., Charriaud E., Craneguy P., and Kartavtseff A., (2001) Fronts, transport, and Weddell Gyre at $30^{\circ}$ E between Africa and Antarctica, Journal of Geophysical Research 106, 2857-2880.

Park Y.H. \& Guernier J.M., (2001) A Simple Method for Diagnosing the Bottom Current Field of the World's Oceans. Journal of Physical Oceanography, 31, 972-991.

Pollard, R.T. and Read, J.F. (2001). Circulation pathways and transports of the Southern Ocean in the vicinity of the Southwest Indian Ridge. Journal of Geophysical Research 106, 2881-2898.

Pollard, R.T., Lucas M.I. \& Read J.F., (2002) Physical controls on biogeochemical zonation in the Southern Ocean. Deep-Sea Research II 49, 3289-3305.

Pond S. \& Pickard G.L., (1983) Introductory Dynamic Oceanography. Pergamon Press.

Read, J. F., \& Pollard R. T., (1999) Deep inflow into the Mozambique Basin, Journal of Geophysical Research, 104, 3075-3090.

Reid,J. L., (2003) On the total geostrophic circulation of the Indian Ocean: flow patterns, tracers, and transports, Progress In Oceanography 56, 137-186.

Rintoul, S. R. \& Bullister J., (1999) A late winter hydrographic section from Tasmania to Antarctica. Deep-Sea Research I 46, 1417-1454.

Robbins, P.E. \& Toole, J.M., (1997) The dissolved silica budget as a constraint on the meridional overturning circulation of the Indian Ocean. Deep-Sea Research I 44, 879-906.

Rodman, M. R. \& Gordon A. L., (1982) Southern Ocean bottom water of the Australian-New 
Zeland sector. Journal of Geophysical Research, 87, 5771-5778.

Sloyan, B. \& Rintoul, S., (2001) The southern ocean limb of the global deep overturning circulation. Journal of Physical Oceanography 31, 143-173.

Schröder, M. \& Fahrbach E., (1999) On the structure and the transport of the eastern Weddell Gyre. Deep-Sea research II, 46, 501-527.

Semtner, A. J. \& Chervin R; M., (1992) Ocean general circulation from global eddy-resolving model. Journal of Geophysical Research, 97, 5493-5550.

Stramma, L. \& Lutjeharms J. R. E., (1997) The flow field of the subtropical gyre of the South Indian Ocean. Journal of Geophysical Research, 5513-5530.

Sultan, E., (2001) Etude de la circulation océanique grande échelle dans l'Océan Indien Sud par méthode inverse, PhD, Muséum National d'Histoire Naturelle, Paris, Fr, 168 pp.

Tarantola, M. \& Valette B., (1982) Generalized nonlinear problems solved using the least square criterion. Review of Geophysics 20 , 219-232.

Tchernia, P. \& Jeannin P. F., (1980) Observations on the Antarctic East Wind Drift using tabular icebergs tracked by satellite Nimbus F (1975-1977). Deep-Sea Research, 27A : 467474.

Toole, J.M. \&. Warren B.A, (1993) A hydrographic section across the subtropical South Indian Ocean. Deep-Sea Research I 40, 1973-2019.

Wacongne, S. \& Pacanowski, R., (1996) Seasonal heat transport in a primitive equations model of the tropical Indian Ocean. Journal of Physical Oceanography 26, 2666-2699.

Warren, B. A., (1981a) Transindian hydrographic section at lat $18^{\circ} \mathrm{S}$ : Property distributions and circulation in the South Indian Ocean. Deep-Sea Research,28A, 759-788.

Warren, B.A., (1981b) The shallow oxygen minimum in the South Indian Ocean. Deep-Sea Research, 28A, 859-864.

Warren, B. A., (1982) The deep water of the Central Indian Basin. Journal of Marine Research, 42, 823-860.

Webb, D., Killworth P. D., Coward A. C. \& Thompson S. R., (1991) The FRAM Atlas of the Southern Ocean, NERC, Swindon, England.

Wunsch, C., (1996) The Ocean Circulation Inverse Problem, Cambridge University Press, New York.

Wyrtki, K., (1971) Oceanographic Atlas of the International Indian Ocean Expedition. National Science Foundation, Washington D.C., 531 pp.

Zhang, Q. \& Marotzke J., (1999) The importance of open-boundary estimation for an Indian Ocean GCM-data synthesis. Journal of Marine Research 57, 305-334. 
$\longrightarrow$ 
Figure Captions

Figure 1: Positions of the 1986 stations selected for the inverse model and the zonal decomposition. The $3500 \mathrm{~m}$ depth contour is included to show the main topographic features referred to in the text.

Figure 2: Objectively analysed horizontal patterns associated with the first 3 EOF's of the density field (see text for details). Negative values are cross-hatched.

Figure 3: Horizontal distribution of (a) salinity, (c) potential temperature and (e) in-situ density at $200 \mathrm{~m}$. Each field is reconstructed from the objectively analysed horizontal patterns associated with the first 12 EOF modes. Associated errors in the reconstructed fields are shown in (b), (d) and (f).

Figure 4 : Sections along $30^{\circ} \mathrm{E}$ of (a) reconstructed Salinity (psu) with the 12 first EOF modes, (b) Salinity (psu) after objective analyses, (c) Difference between (a) and (b). Dashed white lines in (a) and (b) show the 34.75 isoline; and in (c) the -0.05 and 0.05 isolines.

Figure 5 : Top-to-bottom integrated transport (in Sv) associated with each horizontal model grid cell (a) before inversion and (b) after inversion. Grey shading indicates the bottom topography (compare Fig. 1). Associated error (c) after inversion (light grey is the $3500 \mathrm{~m}$ depth surface and dark grey is $1000 \mathrm{~m}$ ).

Figure 6 : Stream function (thin and thick black solid lines) of the top-to-bottom integrated transport shown in Fig. 5(b). Transport contours are given in Sv $\left(1 \mathrm{~Sv}=10^{6} \mathrm{~m}^{3} / \mathrm{s}\right)$. Thick black lines define the Subtropical Gyre (over $185 \mathrm{~Sv}$ ), the Antarctic Circumpolar Current (0.1 - $160 \mathrm{~Sv})$ and the Weddell Gyre (less than -3 Sv). Thick dark grey solid lines are isotherms at $200 \mathrm{~m}$ used as the signatures of the Agulhas Front $\left(\mathrm{AF}: 14^{\circ} \mathrm{C}\right)$, the Subtropical Front (STF: $10.6^{\circ} \mathrm{C}$ ), the Subantarctic Front (SAF: $6^{\circ} \mathrm{C}$ ) and the Polar Front (PF: $\left.2^{\circ} \mathrm{C}\right)$. Light grey lines show the $3500 \mathrm{~m}$ isobath.

Figure 7 : Bottom velocity after inversion superimposed on the bathymetry (grey shaded).

Figure 8 : Same as figure 5 (b) except for the $2000 \mathrm{~m}$ to bottom layer only. The $1000 \mathrm{~m}$ (grey surface), 3000m (light grey surface) and 3500m (black line) depth contours are surimposed.

Figure 9 : Vertical structure of the meridional transport across $32^{\circ} \mathrm{S}$ (dashed line), $26^{\circ} \mathrm{S}$ (solid line) and $20^{\circ} \mathrm{S}$ (bold line). The transport per unit depth (Sv per $100 \mathrm{~m}$ or $10^{4} \mathrm{~m}^{2} / \mathrm{s}$ ) equals the zonally averaged cross-track (positive northward) velocity multiplied by the effective width at each depth level (as in Bryden \& Beal, 2001).

Figure 10 : Upper 2000m (dashed) and 2000m to bottom (bold) transport accumulated along $32^{\circ} \mathrm{S}$ from the east coast of Africa. Bold numbers indicate the transport associated with the different regions shown above the figure, with the cumulative value in the right hand margin. Corresponding estimates for the Crozet basin and for the total transport below $2000 \mathrm{~m}$ as given by Ganachaud et al (2000) (G00) and Robbins and Toole (1997) (RT97) are shown in bold and light italics respectively. 



\begin{tabular}{|l|l|l|l|l|l|l|l|}
\hline $\begin{array}{l}\text { Reference } \\
\text { Level (m) }\end{array}$ & Global mass & \multicolumn{2}{|c|}{$30^{\circ} \mathrm{E}$} & \multicolumn{2}{|c|}{$120^{\circ} \mathrm{E}$} & \multicolumn{2}{c|}{$32^{\circ} \mathrm{S}$} \\
\hline 2000 & 0.19 & 127 & 1.2 & 118.5 & 1.8 & 8.3 & -0.1 \\
\hline 2500 & 0.10 & 150.1 & 1.3 & 141.8 & 2.0 & 8.2 & -0.1 \\
\hline 3000 & 0.20 & 155.4 & 1.3 & 152.4 & 2.1 & 2.9 & -0.2 \\
\hline 3500 & $710-4$ & 159.6 & 1.3 & 161.2 & 2.1 & -1.7 & -0.3 \\
\hline 5500 & $410-2$ & 167.8 & 1.3 & 176.7 & 2.2 & -9 & -0.4 \\
\hline
\end{tabular}

Table 1: Sensitivity to the Level of No Motion of the global mass budget, across the $30^{\circ} \mathrm{E}$, $120^{\circ} \mathrm{E}$ and $32^{\circ} \mathrm{S}$ sections under the constraints of mass, planetary vorticity balance and heat conservation. 


\begin{tabular}{|c|c|c|c|c|c|}
\hline Latitude & $\begin{array}{r}\mathrm{TV}_{\text {cell }} \\
(\mathrm{Sv})\end{array}$ & $\begin{array}{l}\text { Vertical } \\
\text { position }\end{array}$ & $\begin{array}{l}\text { TVHcell } \\
\text { (PW) }\end{array}$ & Method & Reference \\
\hline $18^{\circ} \mathrm{S}$ & $\begin{array}{l}19 \\
3.5\end{array}$ & $\begin{array}{l}\text { DWBC } \\
1000 m \text { to } \\
2000 m\end{array}$ & $\begin{array}{l}-0.79 \\
-0.69 \\
\\
-1.45 \\
-0.53\end{array}$ & $\begin{array}{l}\text { Observations } \\
\text { GFDL+Climato } \\
\text { Indian ocean box inverse model } \\
\text { World ocean box inverse model } \\
\text { Finite difference inverse model }\end{array}$ & $\begin{array}{l}\text { Warren (1981) } \\
\text { Lee and Marotzke (1997) } \\
\text { Fu (1986) } \\
\text { MacDonald (1998) } \\
\text { This study }\end{array}$ \\
\hline $32^{\circ} \mathrm{S}$ & \begin{tabular}{l|}
$27 \pm 30 \%$ \\
14 \\
16 \\
$12 \pm 3$ \\
$10.6 \pm 4$ \\
24.9 \\
20.1 \\
18.6 \\
14.4
\end{tabular} & $\begin{array}{l}\text { DWBC } \\
>1000 \mathrm{~m} \\
<1000 \mathrm{~m} \\
\text { DWBC } \\
<2000 \mathrm{~m} \\
<2000 \mathrm{~m} \\
<2000 \mathrm{~m} \\
<2000 \mathrm{~m} \\
<1400 \mathrm{~m}\end{array}$ & $\begin{array}{l}-0.25 \\
-1 \\
-0.5 \\
-1.3 \\
-1.5 \pm 0.2 \\
-1 \\
-0.84 \\
-0.77 \\
-0.33\end{array}$ & $\begin{array}{l}\text { Indian ocean box inverse model } \\
\text { Observations } \\
\text { GFDL+Climato } \\
\text { World ocean box inverse model } \\
\text { Observations and Silicate constaints } \\
\text { Indian Ocean box inverse model } \\
\text { Observations } 1987 \text { TCA=83.4Sv } \\
\text { Observations + LADCP } 1995 \\
\text { TCA=60Sv } \\
\text { Observations + LADCP } 1996 \\
\text { TCA=55Sv } \\
\text { Finite difference inverse model }\end{array}$ & $\begin{array}{l}\text { Fu (1986) } \\
\text { Toole and Warren (1993) } \\
\text { Lee and Marotzke (1997) } \\
\text { MacDonald (1998) } \\
\text { Robbins and Toole (1997) } \\
\text { Ganachaud et al. (2000) } \\
\text { Bryden and Beal (2000) } \\
\text { Bryden and Beal (2000) } \\
\text { Bryden and Beal (2000) } \\
\text { This study }\end{array}$ \\
\hline Mean & $8.8 \pm 4$ & $<1400 \mathrm{~m}$ & & $\begin{array}{l}\text { Finite difference inverse model } \\
\text { Between } 18^{\circ} \mathrm{S} \text { and } 32^{\circ} \mathrm{S}\end{array}$ & This study \\
\hline
\end{tabular}

Table 2 : Meridional overturning flux estimations. $\mathrm{TV}_{\text {cell }}$ is the meridional mass transport of the overturning cell in Sv. The third column is the depth of the change of the sense of circulation in the cell. TVHcell is the meridional heat flux integrated from the bottom to the surface in PW. DWBC is the Deep Western Boundary Current, GFDL is the geophysical Fluid Dynamics Laboratory (Cox, 1984), $\mathrm{T}_{\mathrm{CA}}$ is Agulhas Current transport. 


\begin{tabular}{|l|l|l|l|l|}
\hline $\begin{array}{l}\text { Latitude } \\
\left({ }^{\circ}\right)\end{array}$ & $\begin{array}{l}\text { Meridional } \\
\text { mass } \\
\text { transport } \\
(\mathrm{Sv})\end{array}$ & $\begin{array}{l}\text { Mean error } \\
\text { in mass } \\
\text { transport } \\
(\mathrm{Sv})\end{array}$ & $\begin{array}{l}\text { Meridional } \\
\text { heat } \\
\text { transport } \\
(\mathrm{PW})\end{array}$ & $\begin{array}{l}\text { Mean error } \\
\text { in heat } \\
\text { transport } \\
(\mathrm{PW})\end{array}$ \\
\hline 10 & -49.2 & 0.7 & -1.9 & 0.02 \\
\hline 11 & -35.0 & 0.6 & -1.4 & 0.02 \\
\hline 12 & -11.4 & 0.6 & -0.7 & 0.01 \\
\hline 13 & -13.8 & 0.6 & -0.9 & 0.01 \\
\hline 14 & -15.2 & 0.5 & -1.0 & 0.01 \\
\hline 15 & -7.7 & 0.5 & -0.8 & 0.01 \\
\hline 16 & -5.2 & 0.5 & -0.8 & 0.01 \\
\hline 17 & -0.4 & 0.4 & -0.2 & 0.01 \\
\hline 18 & -3.7 & 0.4 & -0.5 & 0.01 \\
\hline 19 & -0.8 & 0.4 & -0.2 & 0.01 \\
\hline 20 & -1.7 & 0.4 & -0.3 & 0.01 \\
\hline 21 & 1.0 & 0.4 & 0.0 & 0.01 \\
\hline 22 & -1.7 & 0.4 & -0.3 & 0.01 \\
\hline 23 & -1.6 & 0.3 & -0.3 & 0.01 \\
\hline 24 & -1.6 & 0.3 & -0.4 & 0.01 \\
\hline 25 & -1.5 & 0.3 & -0.4 & 0.01 \\
\hline 26 & -1.6 & 0.3 & -0.4 & 0.01 \\
\hline 27 & -1.6 & 0.3 & -0.3 & 0.01 \\
\hline 28 & -3.2 & 0.3 & -0.4 & 0.01 \\
\hline 29 & -1.6 & 0.3 & -0.3 & 0.01 \\
\hline 30 & -1.6 & 0.3 & -0.3 & 0.01 \\
\hline 31 & -1.6 & 0.3 & -0.3 & 0.01 \\
\hline 32 & -1.7 & 0.3 & -0.3 & 0.01 \\
\hline 33 & -1.0 & 0.3 & -0.2 & 0.01 \\
\hline 34 & 9.6 & 0.3 & 0.2 & 0.01 \\
\hline & & & & \\
\hline
\end{tabular}

Table 3 : Meridional mass and heat transport per $1^{\circ}$ band of latitude and associated mean errors. 


\begin{tabular}{|c|c|c|c|}
\hline Location & $\begin{array}{l}\mathrm{W}_{\text {up }}\left(10^{-5}\right. \\
\mathrm{cm} / \mathrm{s})\end{array}$ & Method & Reference \\
\hline World Ocean & 4 & Stommel and Arons type Model & Warren (1981) \\
\hline Pacific Ocean & 1.3 & Stommel and Arons type Model & Warren (1981) \\
\hline Indian Ocean & 1 & Inverse box model & Fu (1986) \\
\hline Indian Ocean & 3.2 & box model & Stuiver et al. (1983) \\
\hline Pacific Ocean & 1.6 & box model & Stuiver et al. (1983) \\
\hline Indian Ocean & $1.2 \pm 0.7$ & $\begin{array}{l}\text { Box model and } \\
\text { biogeochemical constraints }\end{array}$ & Metzl et al. (1990) \\
\hline $\begin{array}{l}\text { Mozambique } \\
\text { Basin }\end{array}$ & 20 & observations & $\begin{array}{l}\text { Toole and Warren } \\
\text { (1993) }\end{array}$ \\
\hline $\begin{array}{l}\text { Mozambique } \\
\text { Basin }\end{array}$ & 8 to 13 & Observations and moorings & $\begin{array}{l}\text { Read and Pollard } \\
\text { (1999) }\end{array}$ \\
\hline $\begin{array}{l}\text { Indian Ocean } \\
\text { At } 32^{\circ} \mathrm{S}\end{array}$ & 7 & observations & $\begin{array}{l}\text { Toole and Warren } \\
\text { (1993) }\end{array}$ \\
\hline $\begin{array}{l}\text { Indian Ocean } \\
\text { At } 32^{\circ} \mathrm{S}\end{array}$ & 4.5 & $\begin{array}{l}\text { Observations and silicate } \\
\text { constraints }\end{array}$ & $\begin{array}{l}\text { Robbins and Toole } \\
\text { (1997) }\end{array}$ \\
\hline $\begin{array}{l}\text { Indian Ocean } \\
\text { At } 32^{\circ} \mathrm{S}\end{array}$ & $\mathrm{O}(10)$ & Box inverse model & $\begin{array}{l}\text { Sloyan and Rintoul } \\
\text { (2001) }\end{array}$ \\
\hline $\begin{array}{l}\text { Indian Ocean } \\
18^{\circ} \mathrm{S}-32^{\circ} \mathrm{S}\end{array}$ & 1 to 3 & Box inverse model & $\begin{array}{l}\text { Ganachaud et al. } \\
\text { (2000) }\end{array}$ \\
\hline $\begin{array}{l}\text { Indian Ocean } \\
18^{\circ} \mathrm{S}-32^{\circ} \mathrm{S}\end{array}$ & $15.5 \pm 8$ & Finite difference inverse model & This study \\
\hline
\end{tabular}

Table 4 : upwelling velocity ( $\mathrm{w}_{\mathrm{up}}$ ) estimated by different methods. 


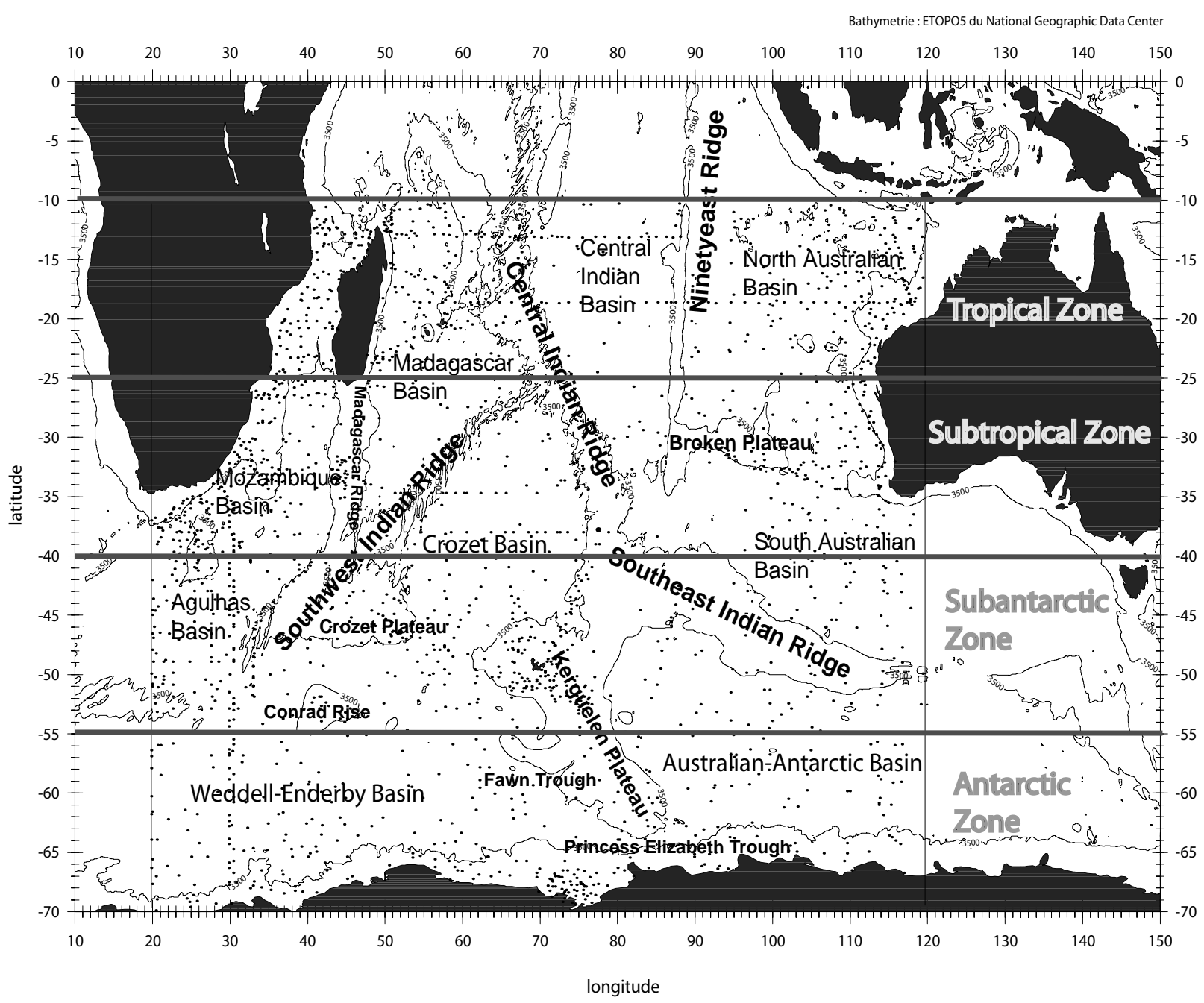

Figure 1: Positions of the 1986 stations selected for the inverse model and the zonal decomposition. The $3500 \mathrm{~m}$ depth contour is included to show the main topographic features referred to in the text. 

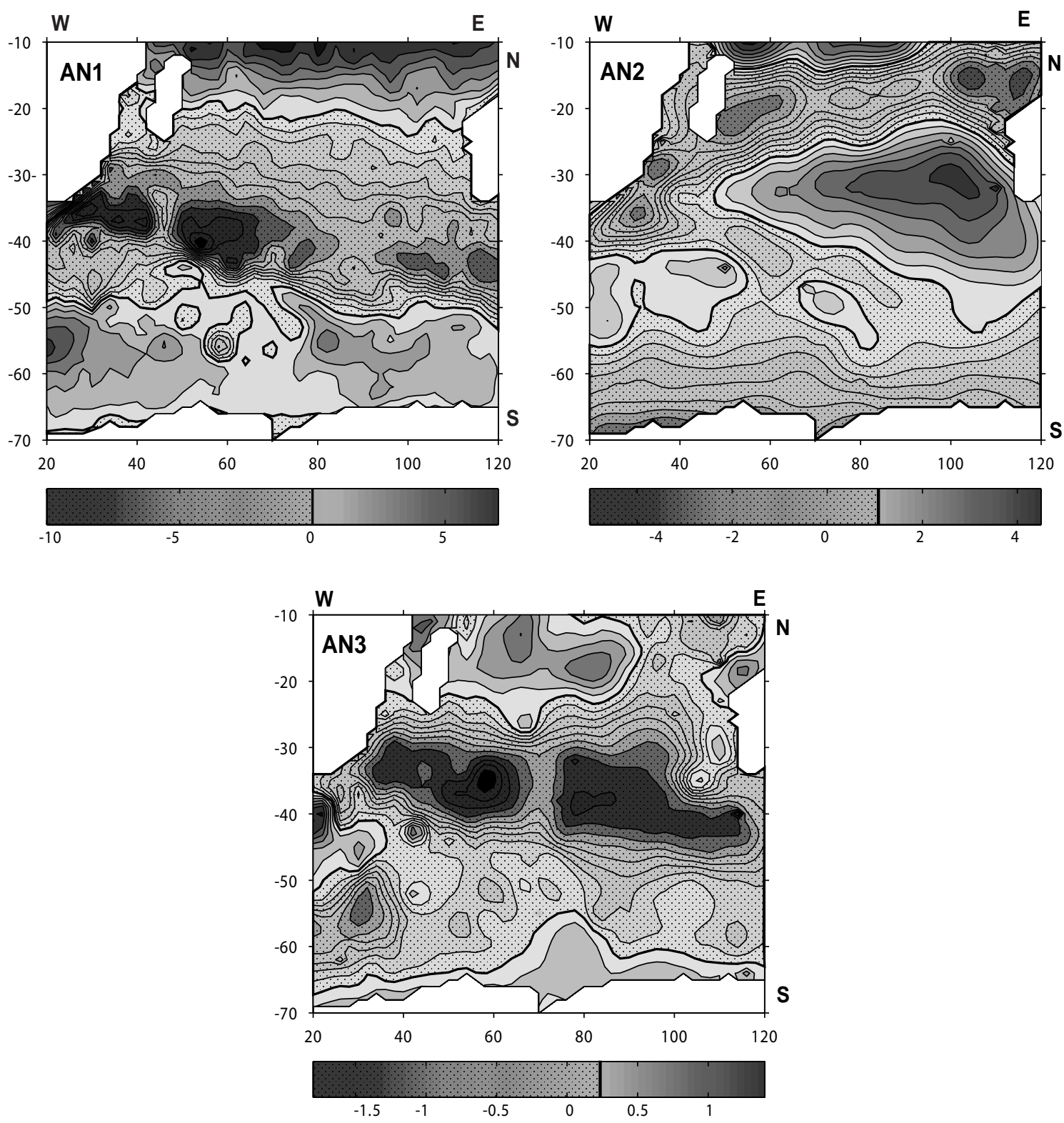

Figure 2: Objectively analysed horizontal patterns associated with the first 3 EOF's of the density field (see text for details). Negative values are cross-hatched. 

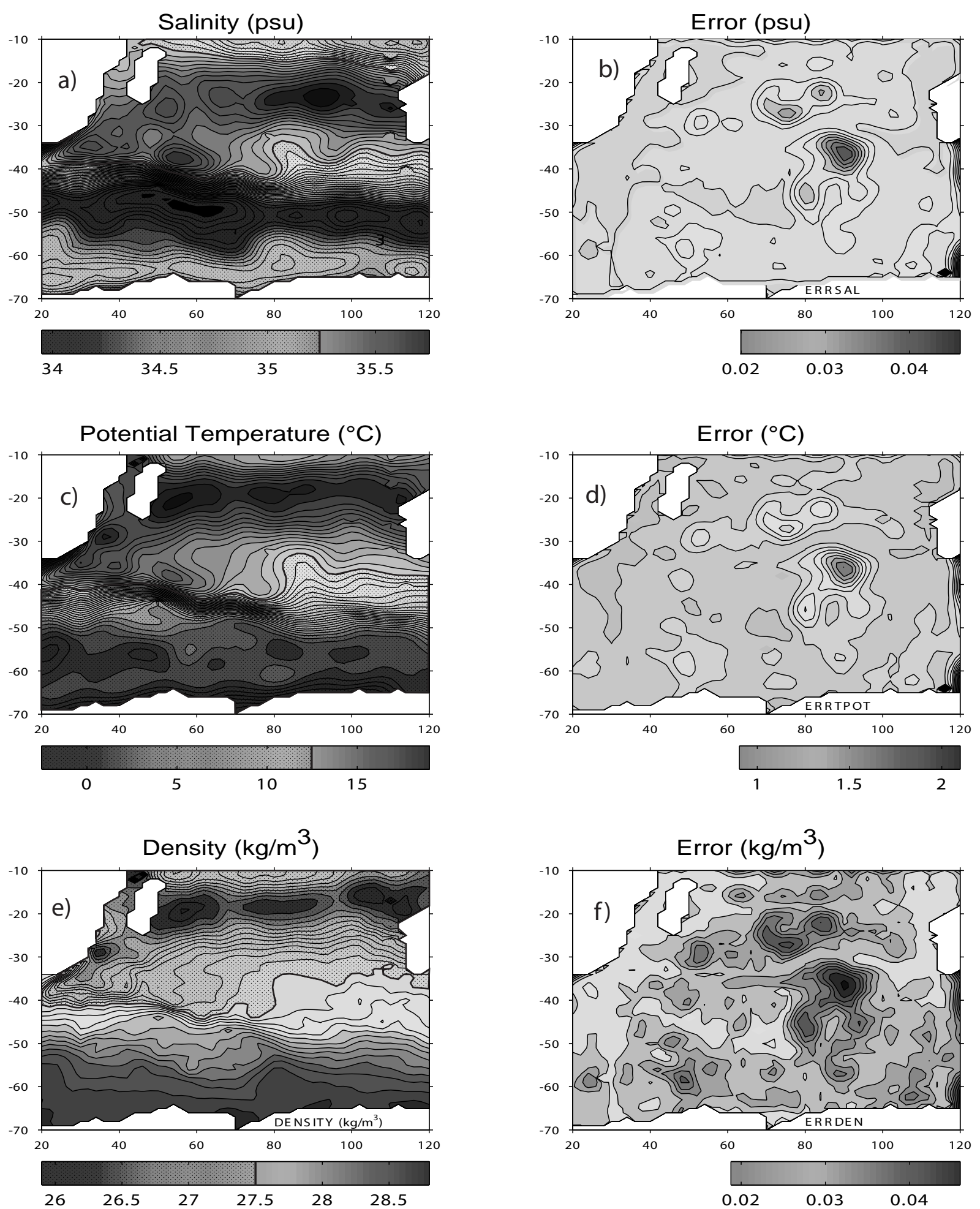

Figure 3: Horizontal distribution of (a) salinity, (c) potential temperature and (e) in-situ density at 200m. Each field is reconstructed from the objectively analysed horizontal patterns associated with the first 12 EOF modes. Associated errors in the reconstructed fields are shown in (b), (d) and (f). 

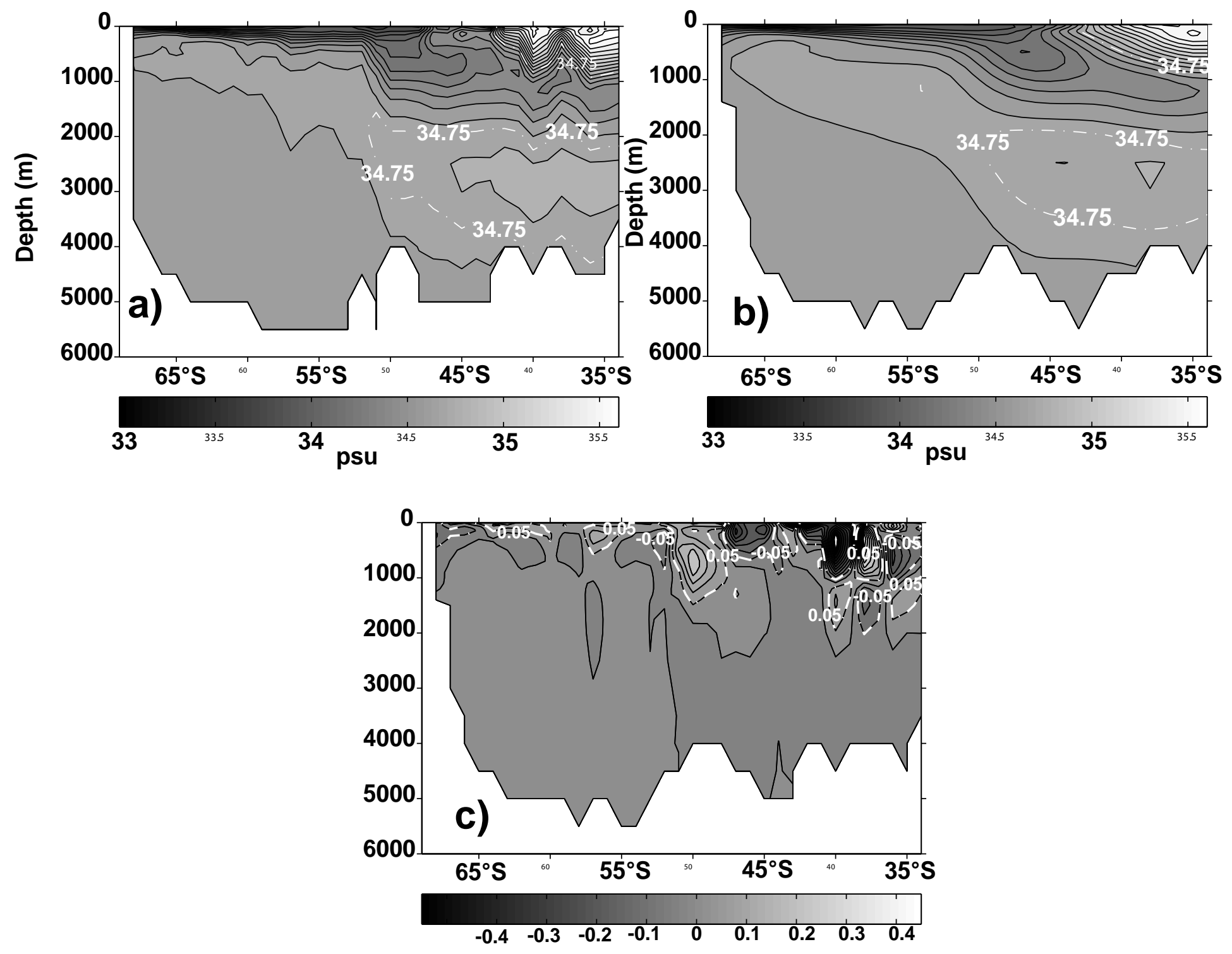

Figure 4 : Sections along $30^{\circ} \mathrm{E}$ of (a) reconstructed Salinity (psu) with the 12 first EOF modes, (b) Salinity (psu) after objective analyses, (c) Difference between (a) and (b). Dashed white lines in (a) and (b) show the 34.75 isoline; and in (c) the -0.05 and 0.05 isolines. 


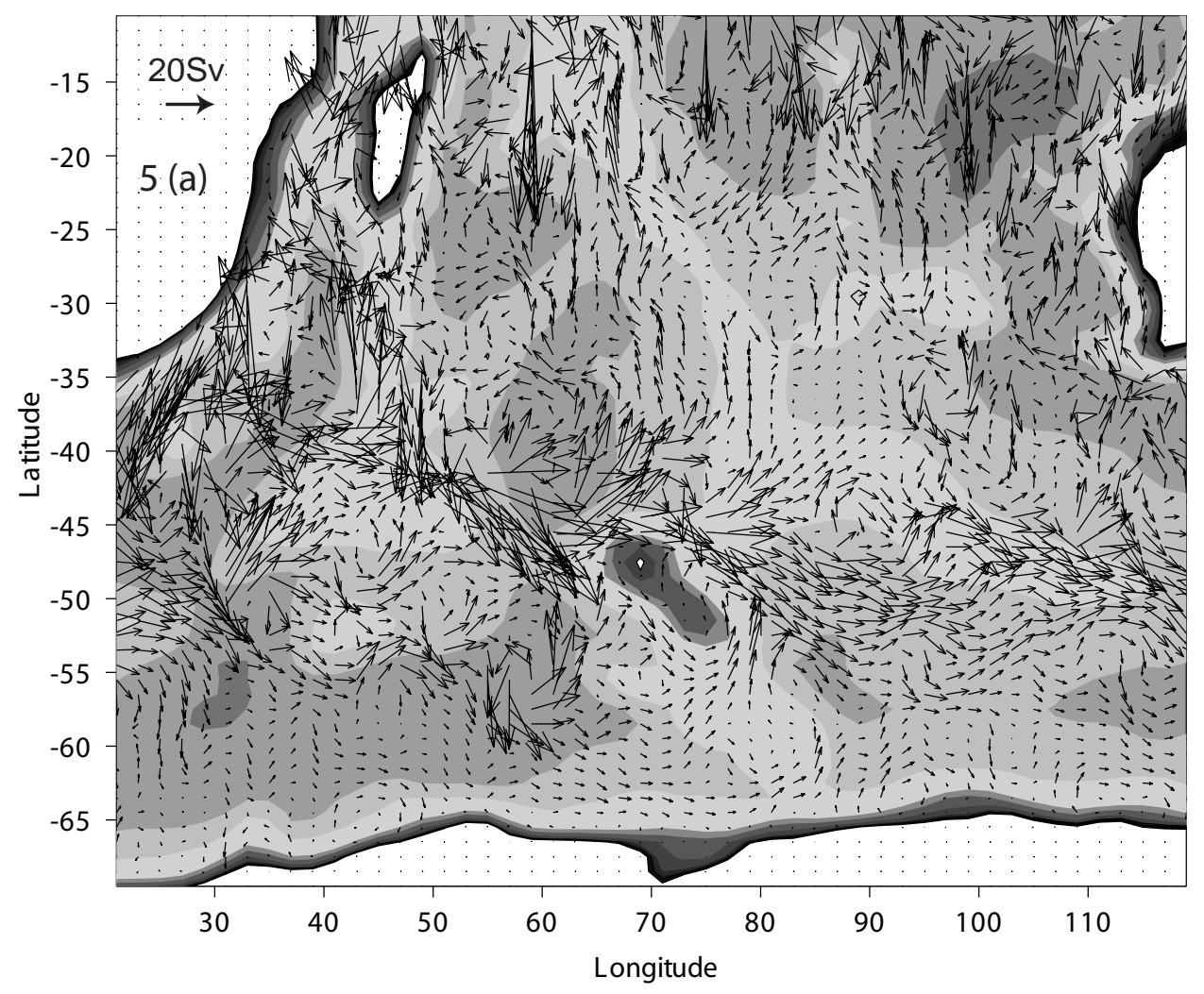

Figure 5 : Top-to-bottom integrated transport (in Sv) associated with each horizontal model grid cell (a) before inversion and (b) after inversion. Grey shading indicates the bottom topography (compare Fig. 1). Associated error (c) after inversion (light grey is the $3500 \mathrm{~m}$ depth surface and dark grey is $1000 \mathrm{~m}$ ). 


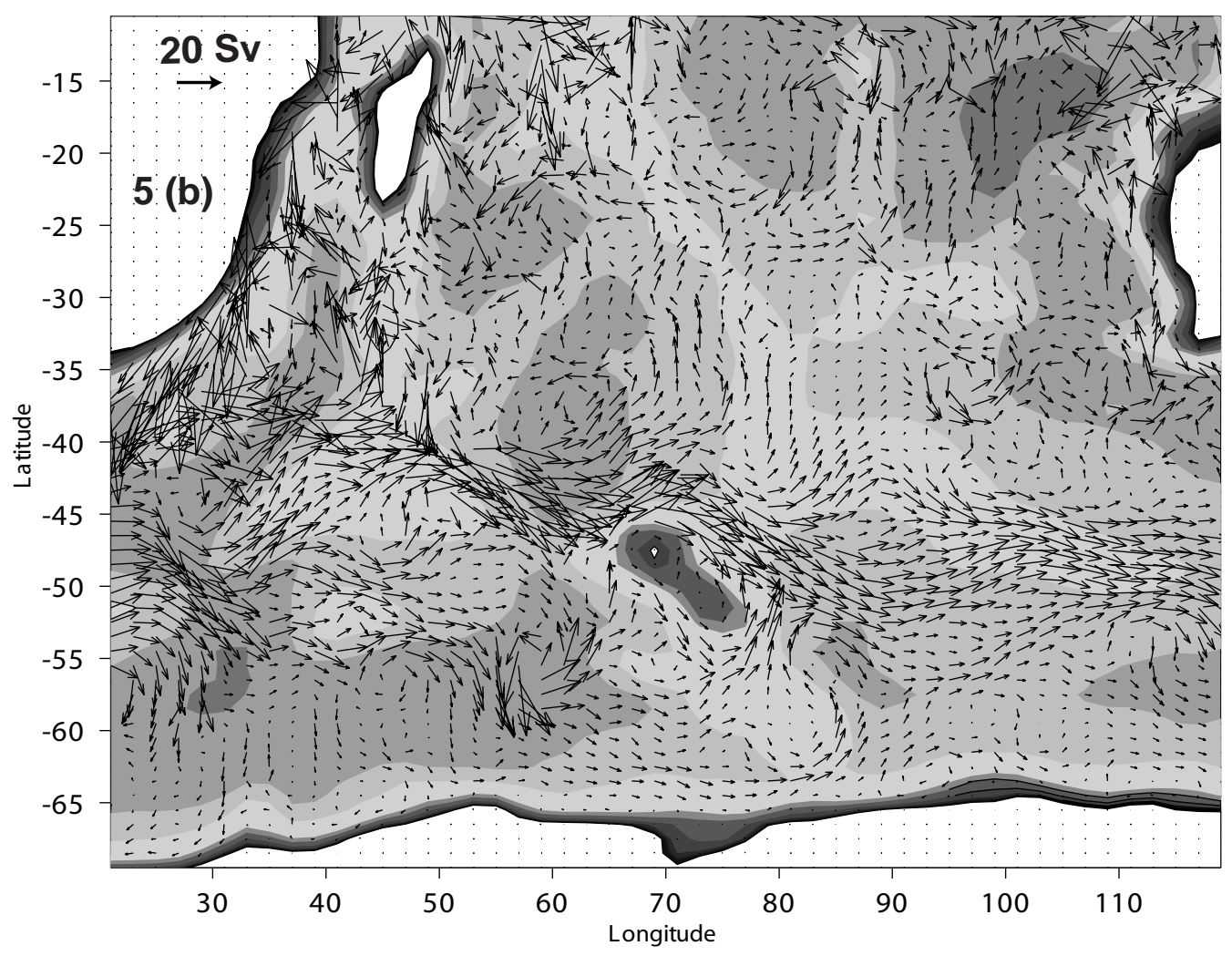




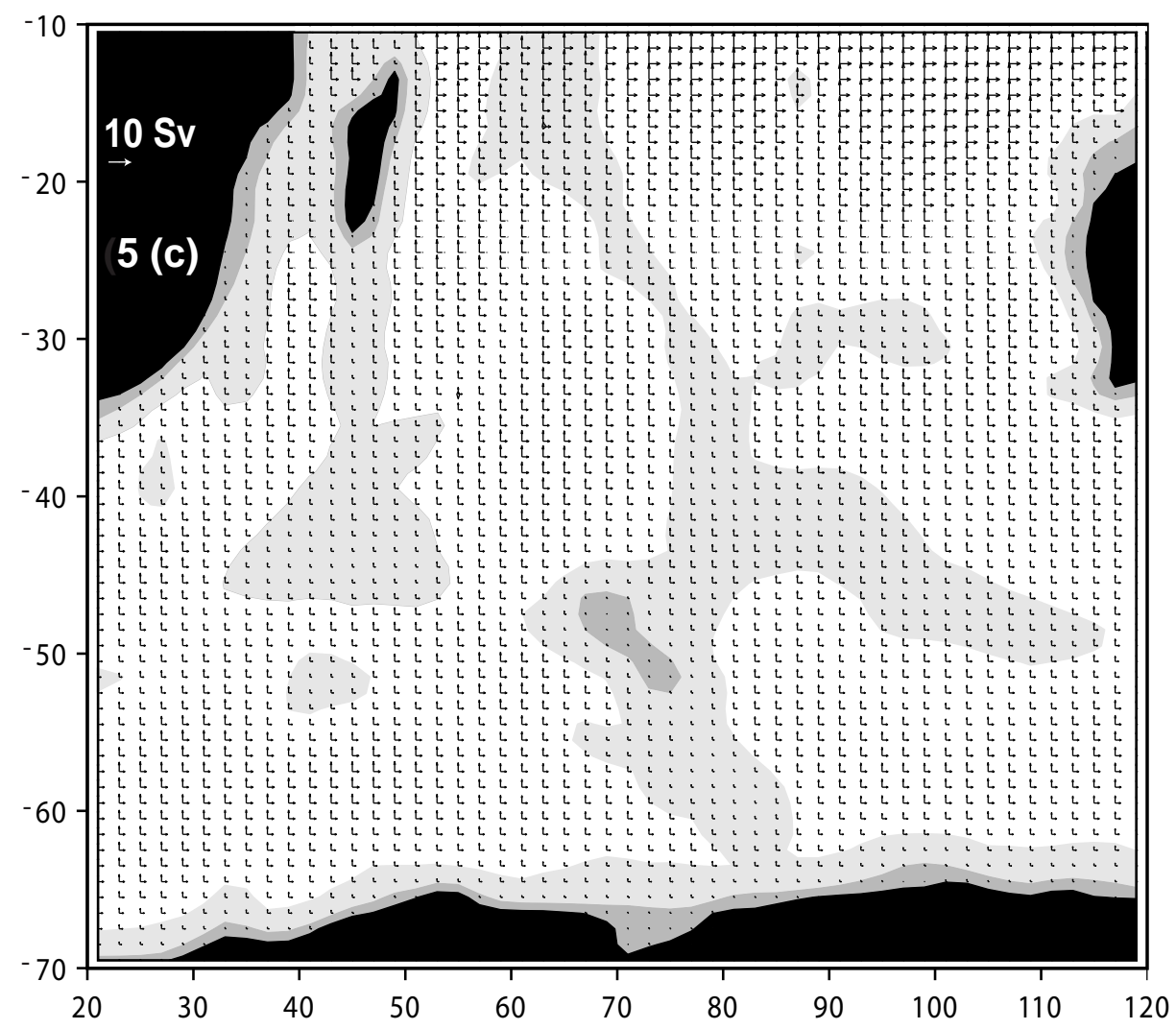




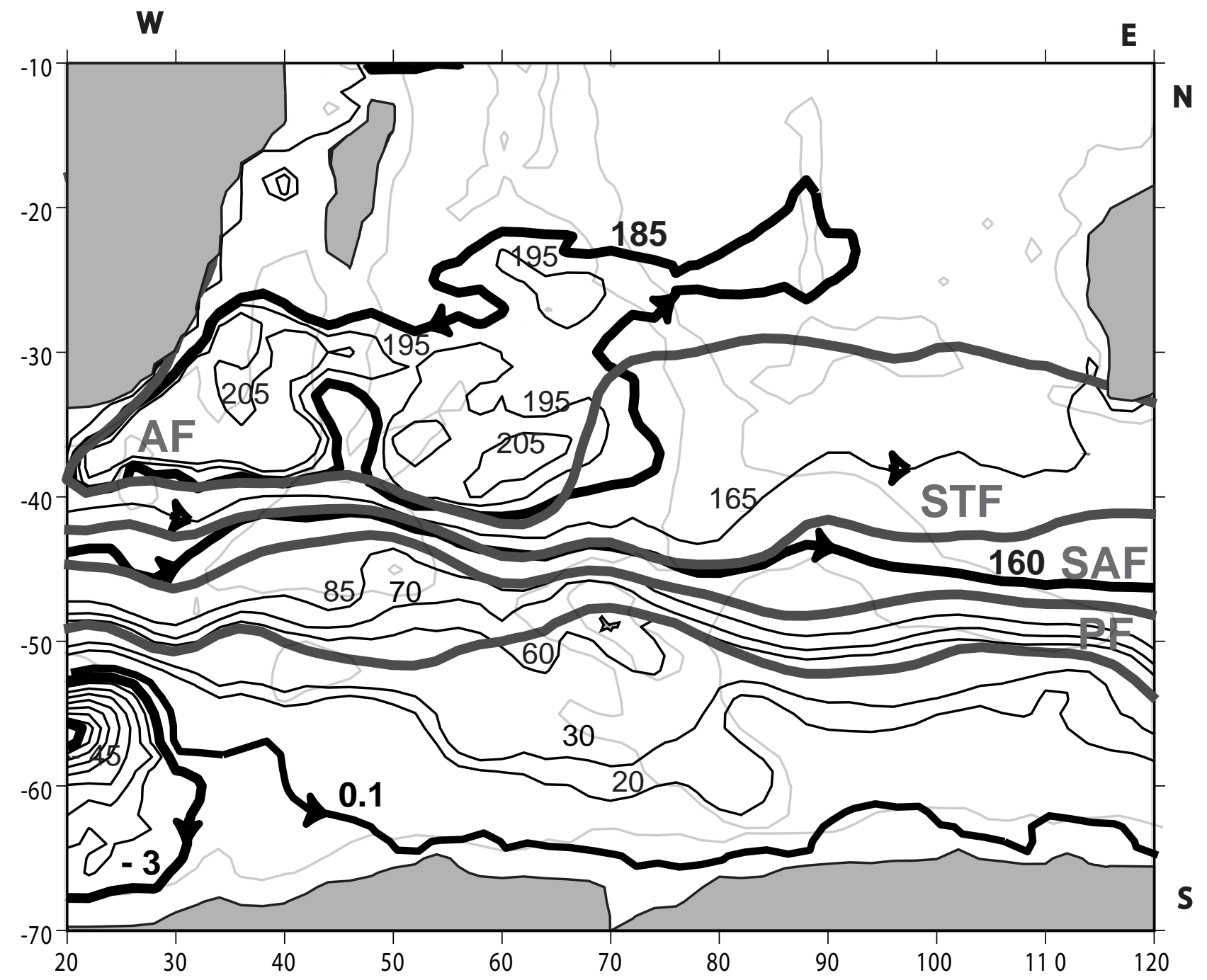

Figure 6 : Stream function (thin and thick black solid lines) of the top-to-bottom integrated transport shown in Fig. 5(b). Transport contours are given in Sv $\left(1 \mathrm{~Sv}=10^{6} \mathrm{~m} / \mathrm{s}\right)$.

Thick black lines define the Subtropical Gyre (over 185 Sv), the Antarctic Circumpolar Current (0.1 - 160 Sv) and the Weddell Gyre (less than -3 Sv).

Thick dark grey solid lines are isotherms at $200 \mathrm{~m}$ used as the signatures of the Agulhas Front (AF: $\left.14^{\circ} \mathrm{C}\right)$, the Subtropical Front (STF: $\left.10.6^{\circ} \mathrm{C}\right)$, the Subantarctic Front (SAF: $\left.6^{\circ} \mathrm{C}\right)$ and the Polar Front (PF: $\left.2^{\circ} \mathrm{C}\right)$.

Light grey lines show the $3500 \mathrm{~m}$ isobath. 


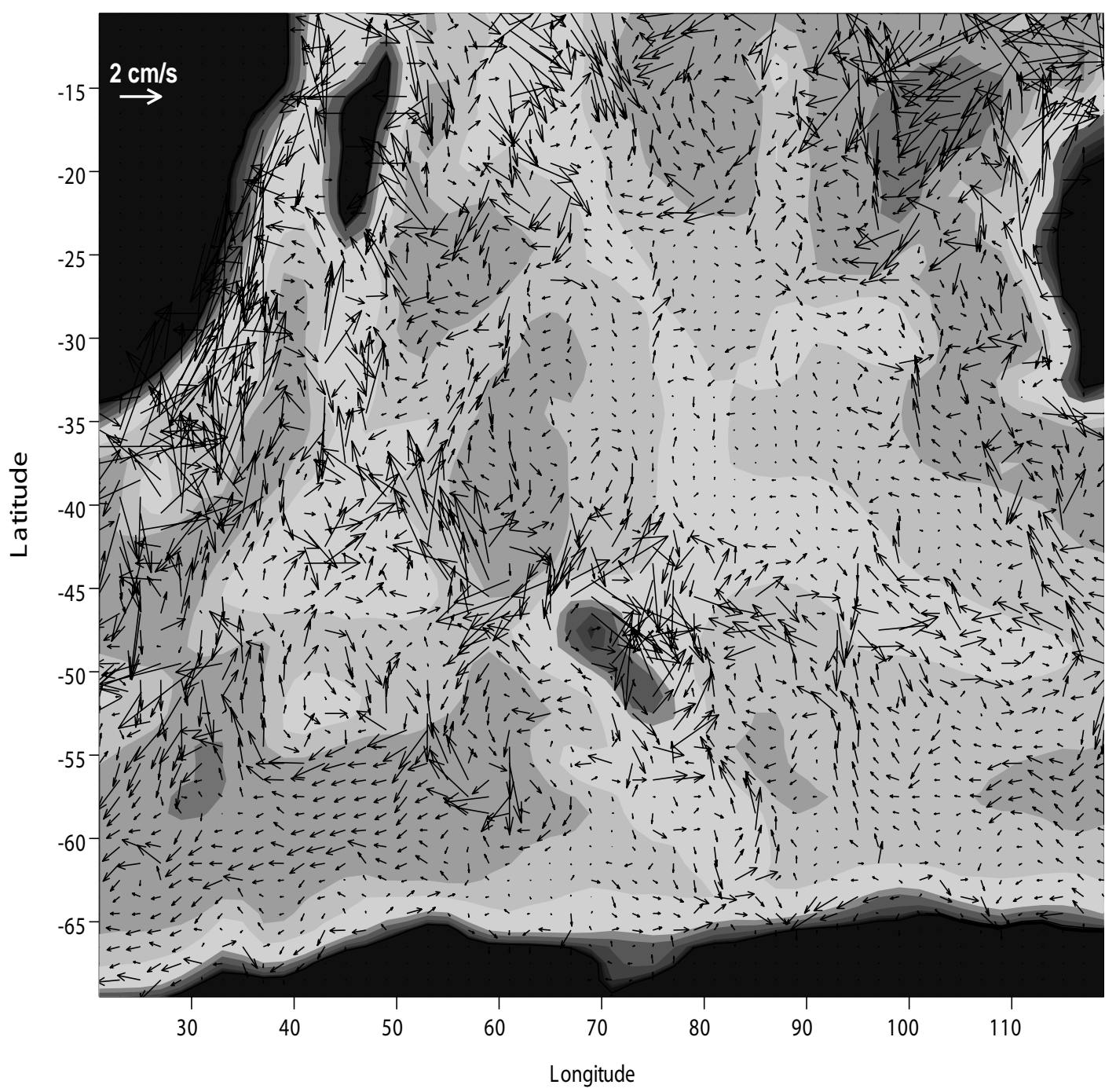

Figure 7 : Bottom velocity after inversion superimposed on the bathymetry (grey shaded). 


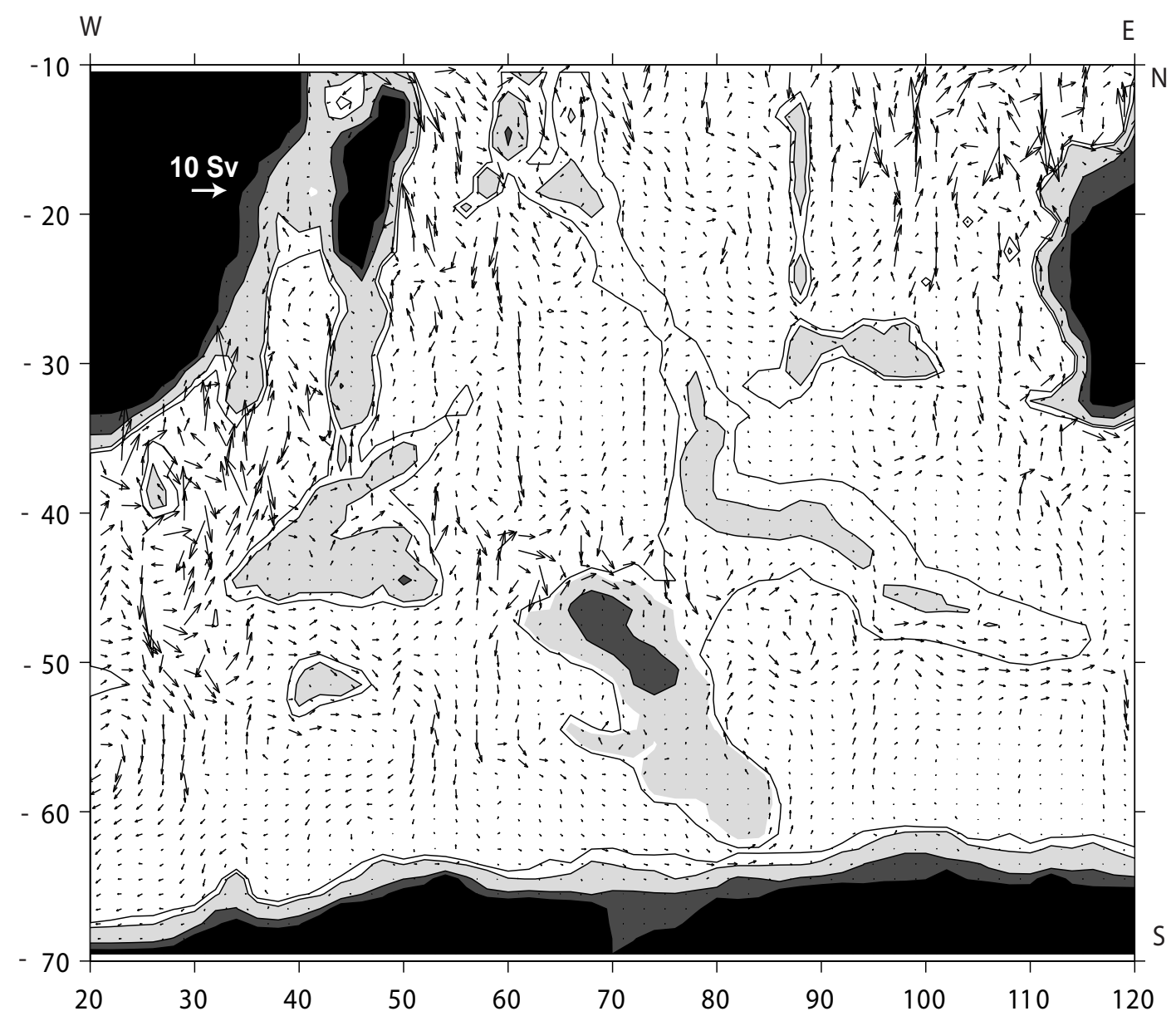

Figure 8 : Same as figure 5 (b) except for the $2000 \mathrm{~m}$ to bottom layer only. The $1000 \mathrm{~m}$ (grey surface), $3000 \mathrm{~m}$ (light grey surface) and $3500 \mathrm{~m}$ (black line) depth contours are surimposed. 
Transport per unit depth (Sv per $100 \mathrm{~m}$ or $10^{4} \mathrm{~m}^{2} / \mathrm{s}$ ) afterinversion

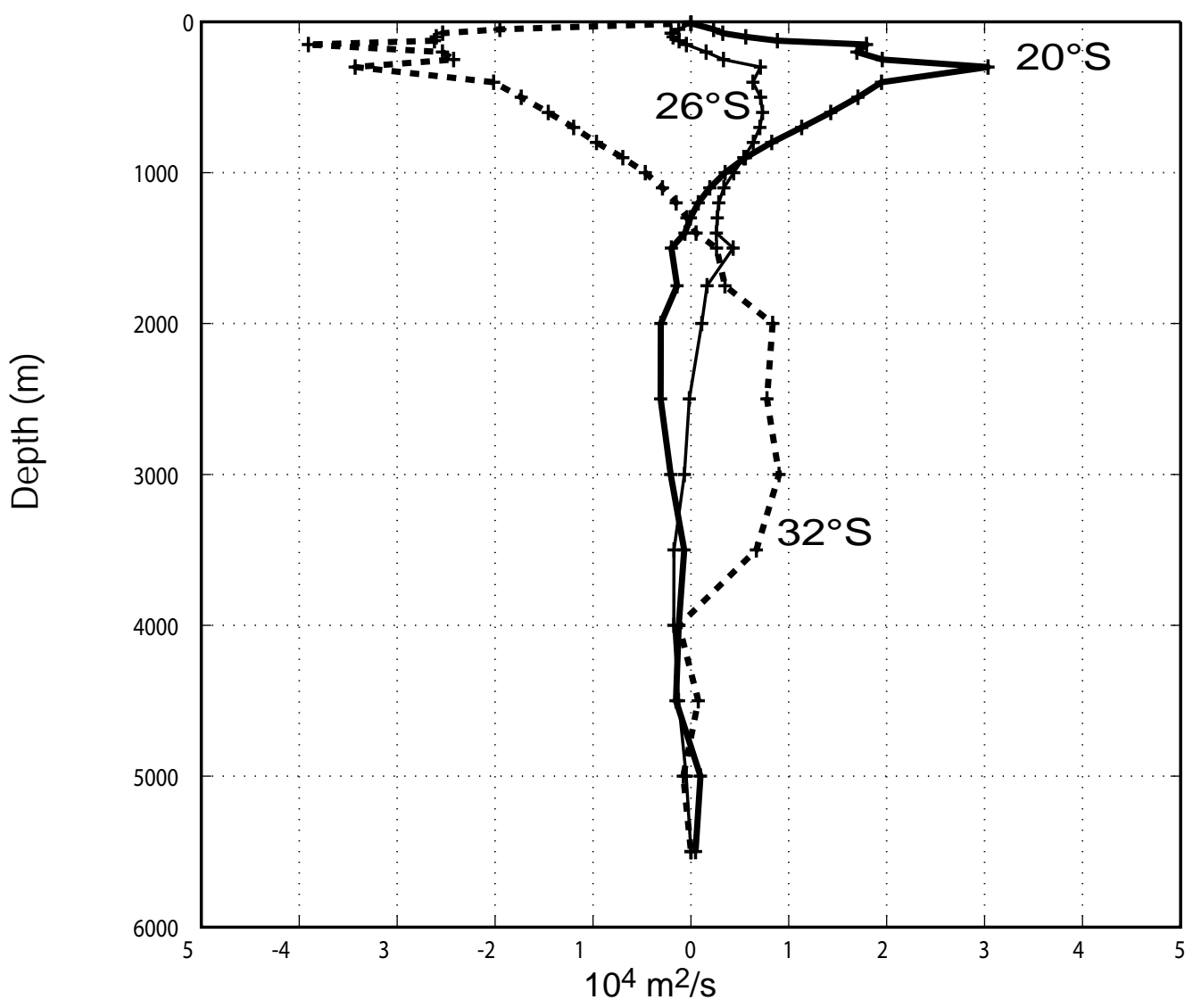

Figure 9 : Vertical structure of the meridional transport across $32^{\circ} \mathrm{S}$ (dashed line), $26^{\circ} \mathrm{S}$ (solid line) and $20^{\circ} \mathrm{S}$ (bold line). The transport per unit depth (Sv per $100 \mathrm{~m}$ or $10^{4} \mathrm{~m}^{2} / \mathrm{s}$ ) equals the zonally averaged cross-track (positive northward) velocity multiplied by the effective width at each depth level (as in Bryden \& Beal, 2001). 


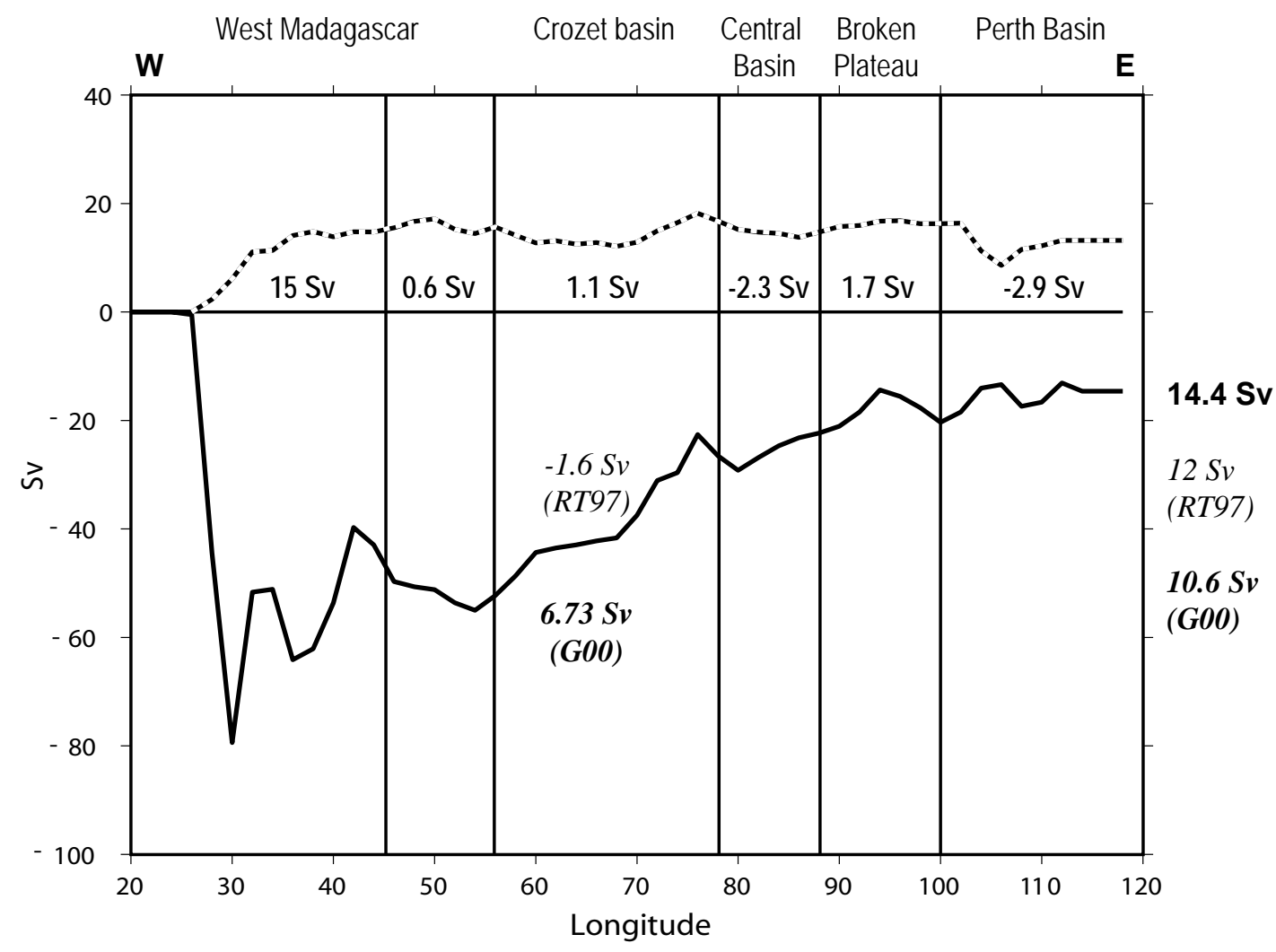

Figure 10 : Upper $2000 \mathrm{~m}$ (dashed) and $2000 \mathrm{~m}$ to bottom (bold) transport accumulated along $32^{\circ} \mathrm{S}$ from the east coast of Africa. Bold numbers indicate the transport associated with the different regions shown above the figure, with the cumulative value in the right hand margin. Corresponding estimates for the Crozet basin and for the total transport below 2000m as given by Ganachaud et al (2000) (G00) and Robbins and Toole (1997) (RT97) are shown in bold and light italics respectively. 